\title{
The Belemnitella stratigraphy of the Upper Campanian-basal Maastrichtian of the Middle Vistula section, central Poland
}

\author{
Zbigniew REMIN ${ }^{1, *}$ \\ 1 University of Warsaw, Faculty of Geology, Żwirki i Wigury 93, 02-089 Warszawa, Poland
}

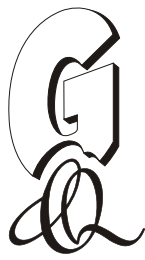

Remin, Z., 2015. The Belemnitella stratigraphy of the Upper Campanian-basal Maastrichtian of the Middle Vistula section, central Poland. Geological Quarterly, 59 (4): 783-813, doi: 10.7306/gq.1257

\begin{abstract}
This taxonomy and stratigraphy of the Upper Campanian and Lower Maastrichtian Belemnitella lineages, from the Middle Vistula section, based on new collections, is presented. The correlation to the basal Maastrichtian standard GSSP at Tercis, France, is provided based on inoceramid bivalve stratigraphy. The artificial neural networks (ANN), particularly the self-organizing Kohonen algorithm, was applied to taxonomic discrimination. Eight morphotypes within the genus Belemnitella, understood here as natural species populations, were recognized. Five of these are assigned to known taxa: Belemnitella mucronata, B. posterior, B. minor (= B. minor I and B. minor II), B. langei and B. najdini; and three, B. sp. a, B. sp. 1 and B. sp. 2 , are left in open nomenclature. Four Belemnitella zones are proposed. Due to its palaeogeographic position, between Western and Eastern Europe, the Middle Vistula section is characterized by the co-occurrence of Belemnitella species from those two areas. Consequently, it enables better correlation of Belemnitella-based schemes; the East European B. najdini and B. posterior are placed next to West European B. minor chronospecies I and II. The Campanian/Maastrichtian boundary, as currently defined, is placed at the top of the najdini-posterior Zone, which is an equivalent of the Belemnella-based boundary, i.e. at the base of the Belemnella obtusa / Belemnella vistulensis zones. Within the top of the najdini-posterior Zone occurs a level (an interval of only a few metres), where nearly all of the Upper Campanian Belemnitella disappear. This level coincides with taxonomic changes observed within the co-occurring representatives of genus Belemnella.
\end{abstract}

Key words: Campanian, Maastrichtian, Vistula section, belemnites, biostratigraphy, artificial neural networks, Campanian/Maastrichtian boundary.

\section{INTRODUCTION}

In the Late Campanian and Early Maastrichtian, belemnites played an important role in marine ecosystems of Europe. Particularly well represented and fast evolving were members of the genus Belemnitella, widely distributed and with high stratigraphic potential. Unfortunately, although a number of biostratigraphic zonations based on this genus were proposed, no uniform Belemnitella subdivision for the whole of Europe exists. Christensen (1999) reviewed Upper Campanian Belemnitella zonation for northwestern Europe and concluded that neither the standard zonation of Jeletzky (1951b) nor Naidin's (1979) zonation, established on the record in Eastern Europe, can be applied there. Consequently, he proposed a new zonation, based on large or very large Belemnitella from Norfolk, England (Christensen, 1995), but again admitted that his new subdivision is only of local significance (Christensen 1999, 2000b). Taking into account the importance of the group in the Campanian and Maastrichtian stratigraphy, the need of

\section{*E-mail: zbyh@uw.edu.pl}

Received: March 25, 2014; accepted: October 26, 2015; first published online: October 30, 2015 establishing a reliable Belemnitella-based subdivision applicable throughout Europe is clear.

In this context, the belemnite record of the Middle Vistula section in Poland is particularly promising. The palaeogeographic position of this area, between Western and Eastern Europe, and its rich and diverse macro- and microfaunal record, offer a unique opportunity to combine the east- and west-European Belemnitella records. These records are constrained in a well-established stratigraphic framework based on various biostratigraphies as well as chemo- and magnetostratigraphy (see Walaszczyk, 2012, as well as Peryt and Dubicka, 2015; Plasota et al., 2015; Remin et al., 2015). The genus Belemnitella from the Vistula section has not been studied since Kongiel's (1962) belemnite monograph.

The present study provides the taxonomic and stratigraphic interpretations of the latest Campanian and earliest Maastrichtian belemnites of the genus Belemnitella from the Middle Vistula section. The correlations of the belemnite succession, as worked out herein, with other groups, as well as with belemnite zonations in other areas, are discussed. Representative and/or topotype material of selected Belemnitella species is presented.

The study has been carried out according to Remin's (2012) methodology, based on artificial neural networks (ANN) (Fausett, 1994; Haykin, 1994; Patterson, 1996), in particular the self-organizing Kohonen networks (Kohonen, 1982), and the integrated biometric procedure, independent of the generic mem- 


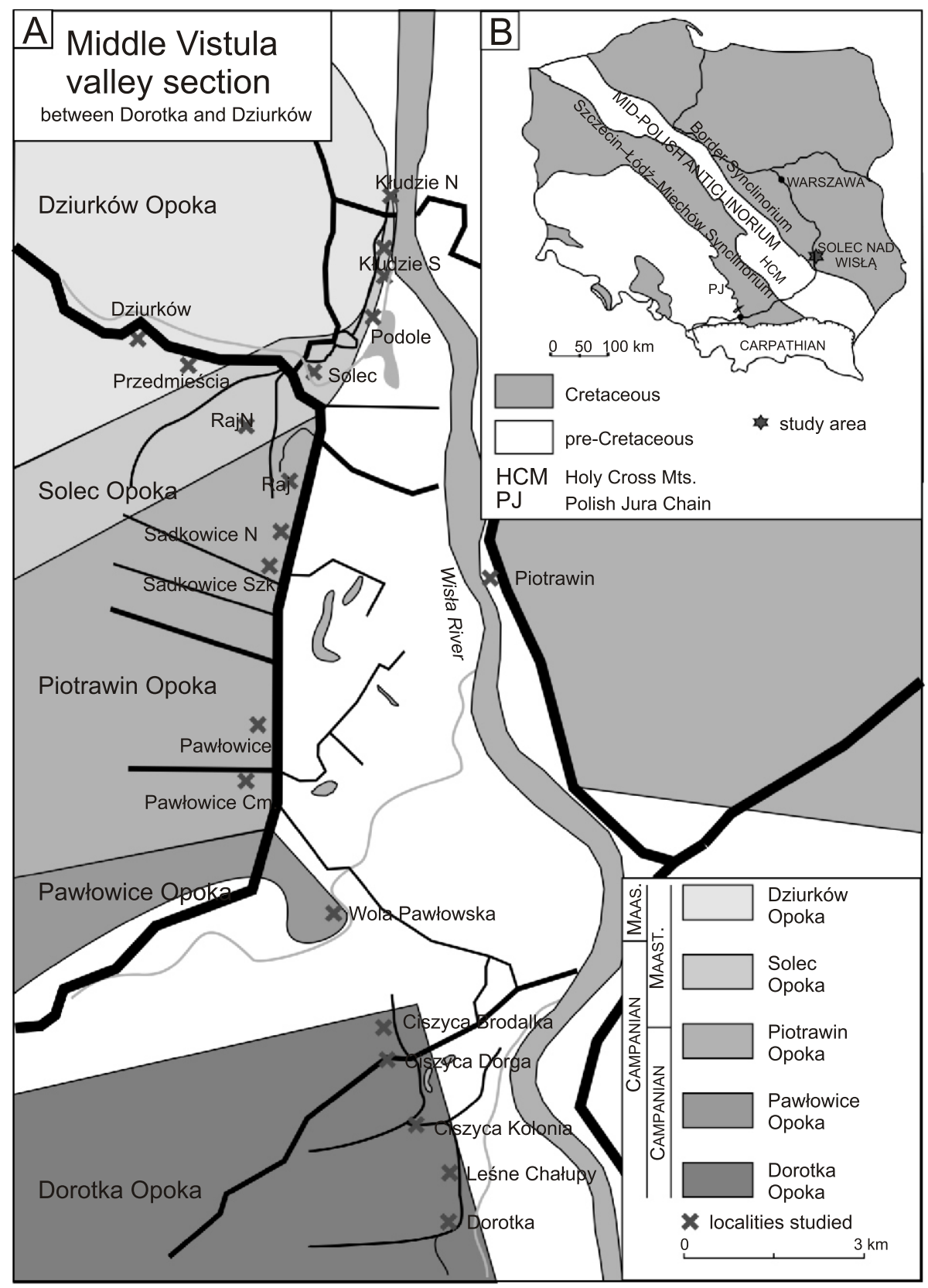

Fig. 1A - geological sketch-map of the Upper Campanian through the Lower Maastrichtian in the Middle Vistula section, central Poland (after Walaszczyk, 2004); B location of the Vistula (Wisła) River in Poland and the Upper Cretaceous deposits in extra-Carpathian Poland (after Pożaryski, 1974)

bership of the material. The powerful algorithm used by Kohonen networks is commonly used to solve different kinds of classification problems and was successfuly applied to species-level taxonomic recognition in belemnites (Remin, 2007, 2008, 2012; Remin in Niebuhr at al., 2011), and e.g., to Paleozoic corals (Wrzołek and Remin, 2008). The study is the first attempt at correlating European Belemnitella populations from different regions, using the new methodological approach and the new integrated biometric procedure.

\section{GEOLOGICAL SETTING, BELEMNITE SUCCESSION AND ORIGIN OF THE STUDIED BELEMNITES}

The Upper Campanian-basal Maastrichtian part of the Middle Vistula section is best exposed in a series of natural and artificial exposures in the left bank of the Vistula River, between the villages of Dorotka and Dziurków (Fig. 1). The Cretaceous forms a homocline, dipping gently to the NE (Fig. 1). The studied interval is composed of white to grey siliceous marls (opoka), referred to the five informal lithostratigraphic units 


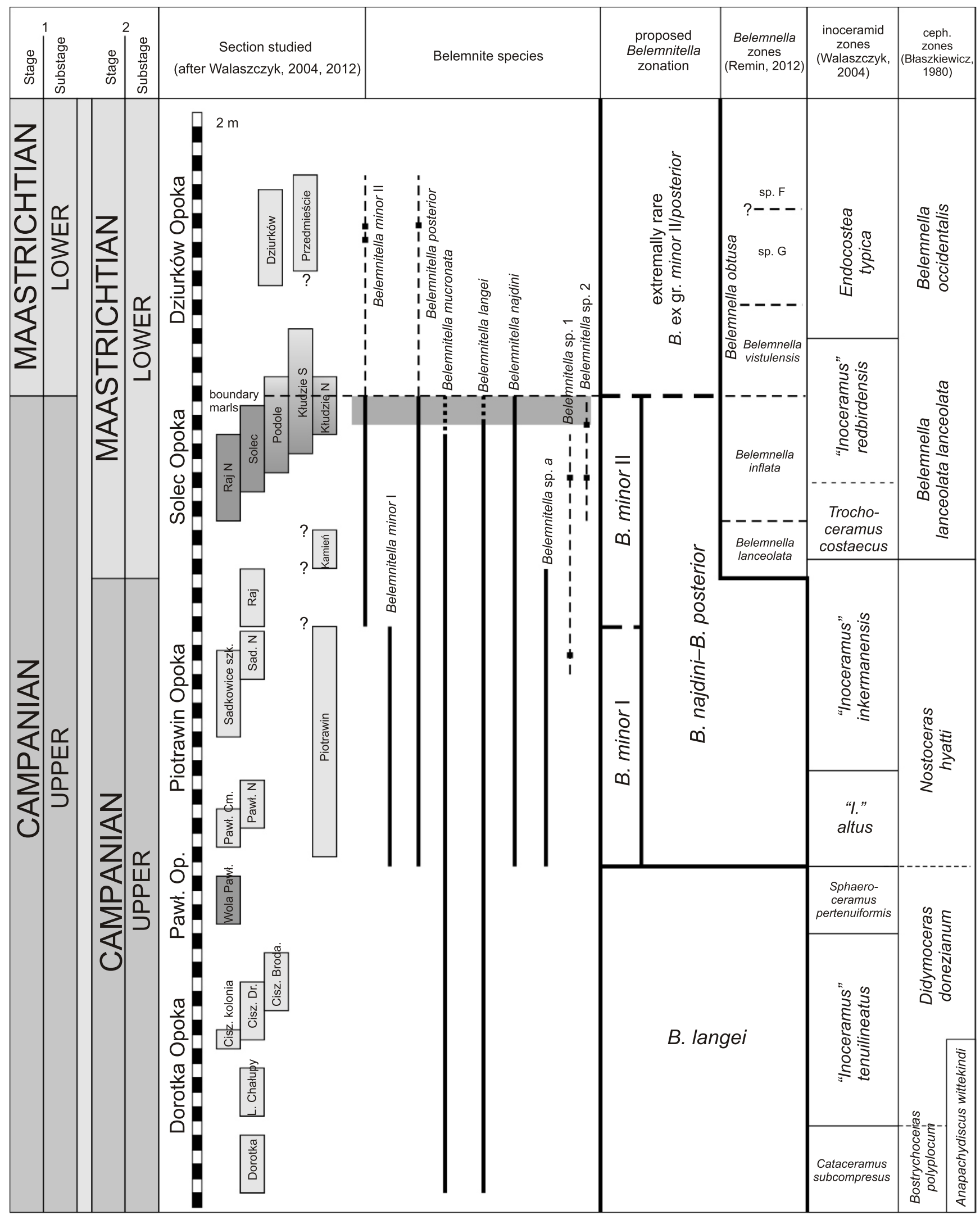

Fig. 2. Stratigraphic ranges of belemnite species and proposed belemnite zonation for the Middle Vistula section, central Poland

Inoceramid zones after Walaszczyk (2004); cephalopod zones after Błaszkiewicz (1980); base of the Maastrichtian according to (1) the stratotype in Tercis, France; (2) the conventional subdivision for the Boreal Realm, based on belemnites; belt below the "boundary marls" show few metres interval where most of the Belemnitella forms disappear 
(Walaszczyk, 2004): Dorotka, Pawłowice, Potrawin, Solec and Dziurków opokas (Figs. 1 and 2).

The lower part of the studied succession, between the villages of Dorotka and Wola Pawłowska (see Figs. 1 and 2), is represented by the Dorotka and Pawłowice opokas units, and has so far yielded only few complete specimens of Belemnitella, represented by B. mucronata and B. langei. In inoceramid terms, this part of the succession belongs to the Cataceramus subcompresus, "Inoceramus" tenuilineatus and Sphaeroceramus pertenuiformis zones of Walaszczyk (2004, 2012).

The higher part of the succession is available in a series of outcrops between Pawłowice Cemetery and Raj, represented by the Piotrawin Opoka. Within this unit the belemnites become more common, culminating in the Sadkowice, Raj and Raj N sections, around the traditionally defined Campanian/Maastrichtian boundary (Boreal definition). In inoceramid terms this interval represents the "Inoceramus" altus and "Inoceramus" inkermanensis zones of Walaszczyk (2004; Fig. 2).

Starting from the top of the Raj section, Belemnitella is accompanied by Belemnella (Remin, 2012), which tends to dominate, with simultaneous frequency decrease in Belemnitella. This is the uppermost part of the "Inoceramus" inkermanensis Zone and the lower part of the Trochoceramus costaecus inoceramid Zone and the lower part of the Belemnella lanceolata Zone (Fig. 2).

The succession of Raj N represented by the Solec Opoka, is relatively rich in belemnites, dominated by Belemnella. It represents the "Inoceramus" redbirdensis Zone and the Belemnella inflata Zone.

Still higher, the sections of Podole, Kłudzie S and Kłudzie N contain the "boundary marls", a marly bed, which lies between the Solec and Dziurków opokas. Belemnitellas in the interval close to the "boundary marls" are very rare; $B$. ex gr. minor II/posterior (cf. Fig. 2) is the only form which crosses the "boundary marls". In inoceramid terms, this interval belongs to the "Inoceramus" redbirdensis Zone; in Belemnella terms it is an equivalent of the Belemnella inflata and lower part of the Belemnella obtusa zones.

The two youngest sections, Przedmieścia and Dziurków, represented by the Dziurków Opoka, yielded only single specimens of $B$. ex gr. minor II/posterior. This part of the succession belongs to the Endocostea typica inoceramid Zone (Walaszczyk, 2004, 2012). In Belemnella terms it represents the Belemnella obtusa Zone of Remin (2012).

The whole studied succession yielded >140 complete Belemnitella guards and several dozen more or less incomplete specimens. Also available for study are the large collections of Pożaryski, Błaszkiewicz and Kongiel, housed in the Museum of the Earth of the Polish Academy of Science, Warsaw, and in the Museum of the Polish Geological Institute in Warsaw.

\section{BIOSTRATIGRAPHY}

Traditionally in Europe, the Campanian was subdivided into Lower and Upper substages, with the boundary between them placed at the extinction level of the belemnite genus Gonioteuthis (i.e. Jeletzky, 1958). Belemnites were also used to define the base of the Maastrichtian stage and of the Lower/Upper Maastrichtian boundary, with the FADs of Belemnella lanceolata (Schlotheim, 1813) and Belemnitella junior (Nowak, 1913) respectively (e.g., Arkhangelsky, 1912; Jeletzky, 1951a, b).

During the 1995 Brussels Symposium, it was agreed that the Campanian stage should be subdivided into three substages of possibly equal duration (Hancock and Gale, 1996). Also discussed was the new definition of the base of the Maastrichtian Stage (Odin, 1996). The latter was finally defined as an arithmetic mean of twelve bio-events and placed at the $115.2 \mathrm{~m}$ level of the Tercis section (Odin, 2001), the GSSP for the base of the Maastrichtian stage, and ratified then by the International Commission on Stratigraphy in 2001 (Odin, 2001; Odin and Lamaurelle, 2001).

\section{TRADITIONAL BELEMNITELLA-BASED ZONATION}

After the belemnite extinction at the end of the Early Campanian, only a single belemnite genus Belemnitella (d'Orbigny, 1840), represented by a single species, Belemnitella mucronata (Schlotheim, 1813), persisted in the later Campanian (see Christensen, 1997a, b). In the Middle and Late Campanian (e.g., Christensen, 1997a, b), Belemnitella speciated and expanded geographically. The newly evolved species provided the basis for the biostratigraphic subdivisions of the Middle and Upper Campanian, which differ geographically (Fig. 3).

The Upper Campanian, in the Boreal definition, of northwestern Europe was subdivided into three belemnite zones (Jeletzky, 1951), in ascending order the Belemnitella mucronata, B. minor and B. langei zones (Fig. 3). According to Christensen $(1995,1996,1999)$, the zones of $B$. minor and B. langei of Jeletzky (1951b) should be abandoned.

The belemnite zonation for the Upper Campanian of Eastern and Central Europe was proposed by Najdin (1964a, b, 1975, 1979; see Fig. 3), who distinguished the B. mucronata Zone (lower) and $B$. langei Zone (upper). The latter zone he subdivided into (in ascending order): $B$. langei minor, $B$. langei langei, and $B$. langei najdini zones (cf. Fig. 3). Christensen (1995, 1996, 1999, 2000b) criticized this zonation, arguing that $B$. minor should neither be considered a subspecies of $B$. langei, as proposed by Naidin (1979), nor be placed into the $B$. langei group as suggested by Kongiel (1962).

Peake and Hancoock $(1961,1970)$ and Wood (1988) proposed slightly different Belemnitella zonations, based on the record in the Upper Campanian of Norfolk, eastern England. Christensen (1995) reinvestigated the Norfolk belemnite material, and proposed a zonation based mainly on newly erected species: B. mucronata, B. woodi, B. minor I, B. minor II and $B$. minor III (= B. minor Il; cf. Fig. 3). Christensen (1999) suggested that his new zonation might be regarded a standard Belemnitella zonation in Europe. However, in 2000, he rejected his previous opinion and concluded that the Belemnitella zonation of Norfolk was no longer applicable throughout Europe (although it can be applied in the Maastricht area of the Netherlands; see Keutgen, 2011).

After the sudden appearance of Belemnella lanceolata and of the so-called "primitive" Belemnella, i.e., B. licharewi Jeletzky, 1941, representatives of Belemnella became dominant across Europe; in many areas this genus almost completely replaced the genus Belemnitella. Consequently, the belemnite stratigraphic subdivision of the Lower Maastrichtian is based primarily on Belemnella (see discussion in Remin, 2012).

\section{NEW BELEMNITELLA-BASED ZONATION} OF THE MIDDLE VISTULA SECTION

The biometric procedure, with the use of the artificial neural networks (ANN), particularly the self-organizing Kohonen algorithm, applied herein, follows Remin (2012; see this paper for presentation of the method), who also discussed and compared 


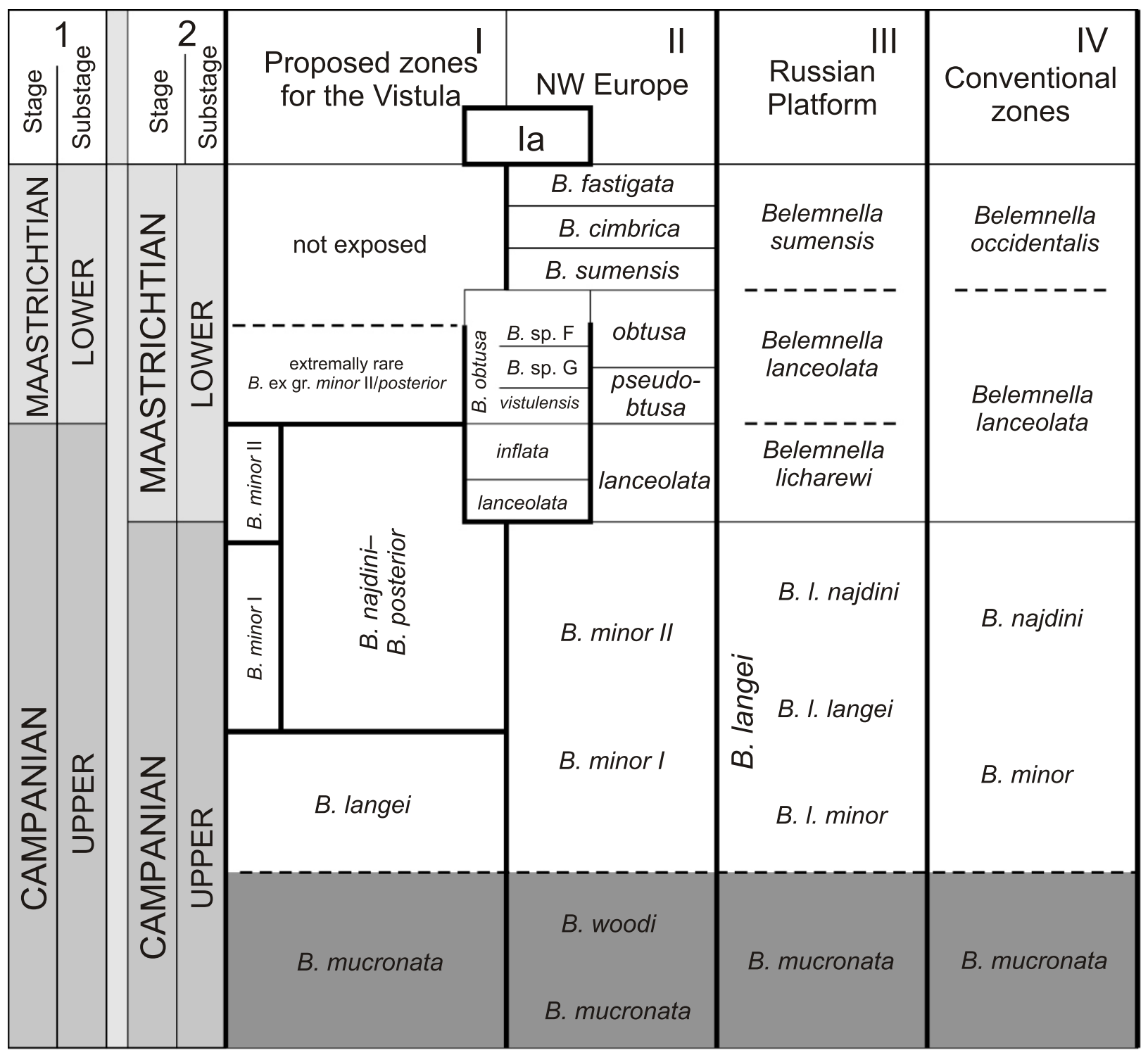

Fig. 3. The correlation of proposed belemnite zones

I - Middle Vistula section (central Poland) - this article; la - Belemnella zones of the Middle Vistula section (Remin, 2012); II - NW Europe, Belemnella zones after Schulz (1979), Belemnitella zones (after e.g., Christensen, 1995, 1999, 2000b); III - Russian Platform (e.g., Naidin, 1975, 1979); IV - conventional belemnite zones (Jeletzky, 1951a, b, 1958; Birkelund, 1957); base of the Maastrichtian according to (1) the stratotype in Tercis, France; (2) the conventional subdivision for the Boreal Realm, based on belemnites

his new method with the former methods of Kongiel (1962), Christensen (1975) and Schulz (1979). The terms and measurements used for belemnites description follow Christensen (1995) and Remin $(2008,2012)$ and are summarized in Figure 4.

\section{RECOGNITION OF BELEMNITELLA SPECIES BY THE KOHONEN NEURAL NETWORKS AND STATISTICAL VERIFICATION OF THE MORPHOGROUPS}

The material studied was subdivided into three stratigraphic samples, each consisting of a sufficient number of guards: (1) Sadkowice Szkoła-Sadkowice N; (2) Raj and (3) Raj N-Dziurków (Raj N, Podole, Kłudzie, Przedmieścia and Dziurków). Belemnites from each stratigraphic sample were ana- lysed independently using a two-layered Kohonen neural network with 29 inputs (29 characters of the guard; Fig. 5). The structures of applied SOM (self-organizing maps) are shown in Figure 5. For testing purpose, two independent simulations were executed on the belemnite guards from the Pawłowice Cemetery, Pawłowice Posesja, and Piotrawin sections, equivalent sections of the stratigraphic samples (1) and (2). Every single guard, from the test sections, was subjected to simulation using a Kohonen networks trained on the material from stratigraphic samples (1) and (2), and classified to one of the morphogroups recognized in them. In a similar way the material from the sections of Dorotka, Leśne Chałupy, Ciszyca, Ciszyca Brodalka and Wola Pawłowska was analysed. Belemnite guards from those locations were subjected to Kohonen networks trained on the material from stratigraphic samples (1 and 2).

$>140$ newly collected complete guards of Belemnitella were subdivided by the Kohonen networks into morphogroups re- 


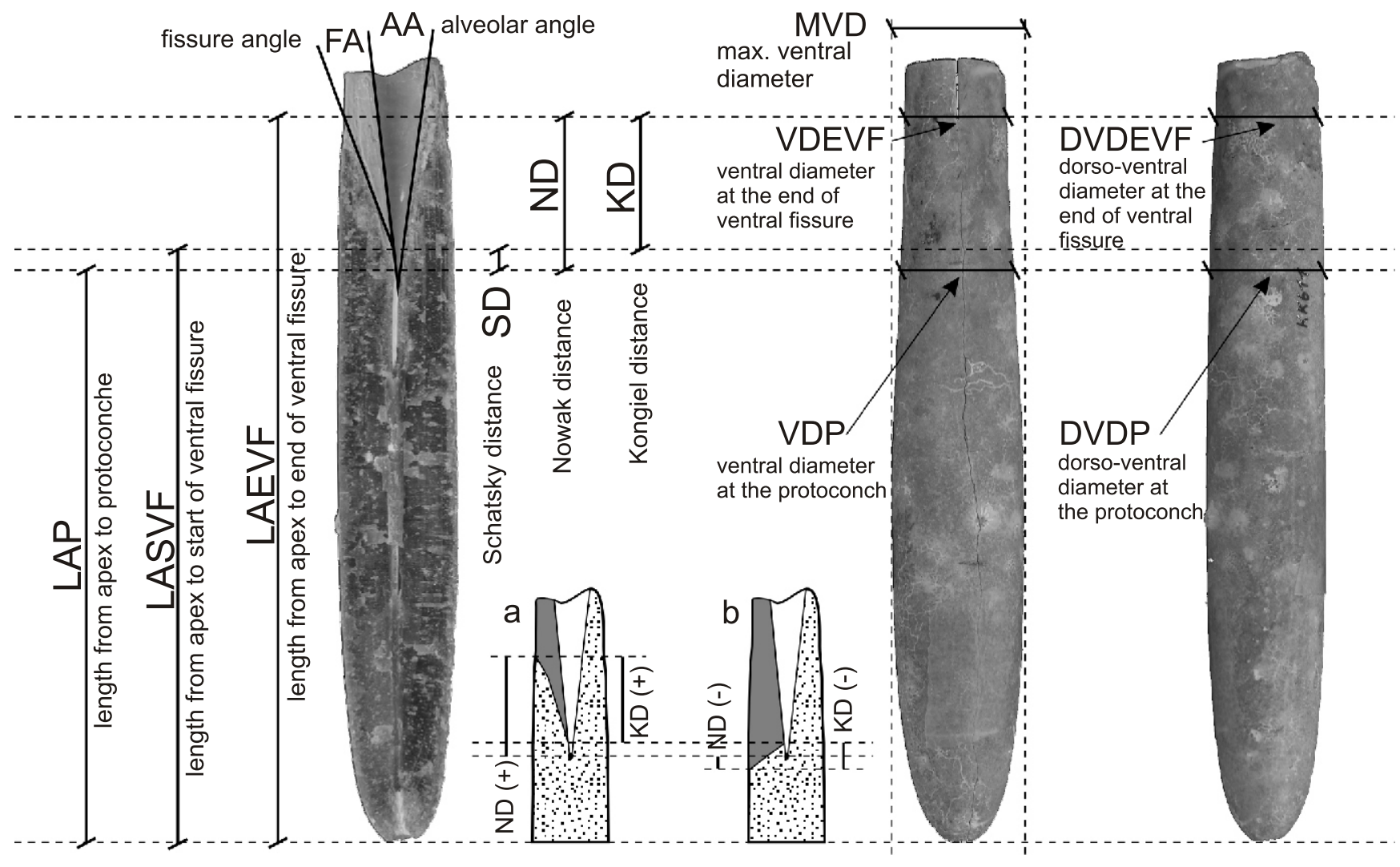

Fig. 4. Terminology and measurements of external and internal features of belemnite guard (Remin, 2008)

Two not illustrated features are: LABVF - length from apex to most posterior part of ventral fissure; RDBSVF (= LASVF - LABVF), for details see Remin $(2008,2012) ; \mathbf{a}, \mathbf{b}$ - the internal structure of the guard and different position of the bottom of the ventral fissure: $\mathbf{a}-\mathrm{ND}(+)$ and KD $(+)$ are positive $(+)$ when the outer end of the bottom of ventral fissure is swept forward from the protoconch and from the inner end of the bottom of the ventral fissure respectively; $\mathbf{b}-\mathrm{ND}(-)$ and $\mathrm{KD}(-)$ are negative $(-)$, when the outer end of the bottom of the ventral fissure is swept back from the protoconch and from the inner end of the bottom of the ventral fissure respectively

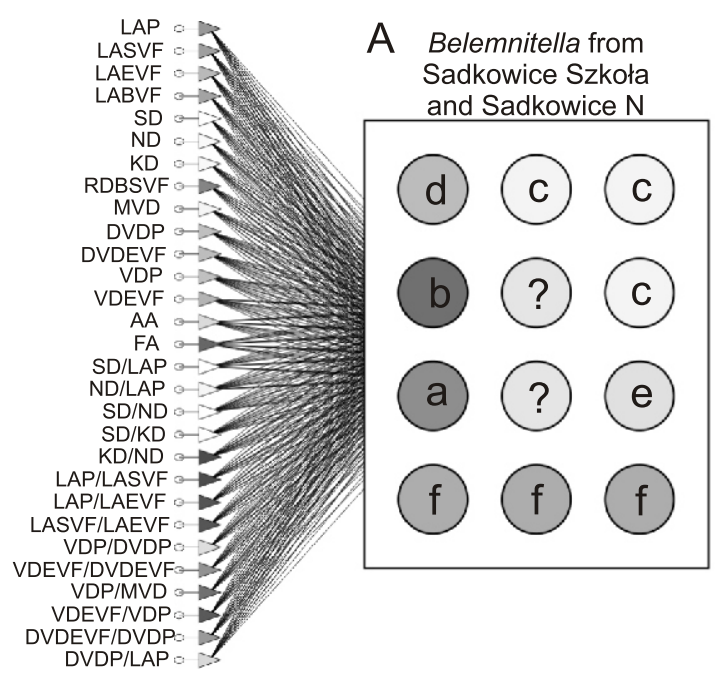

B

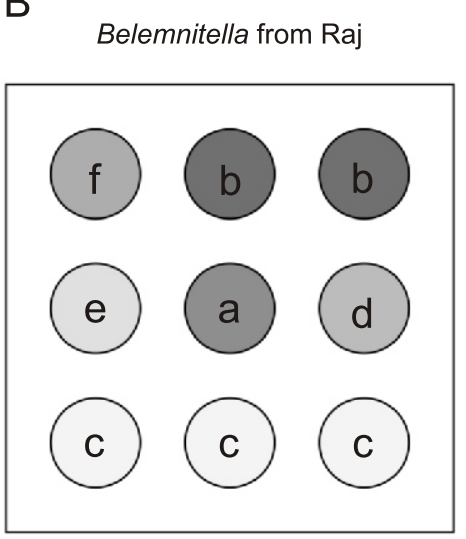

C

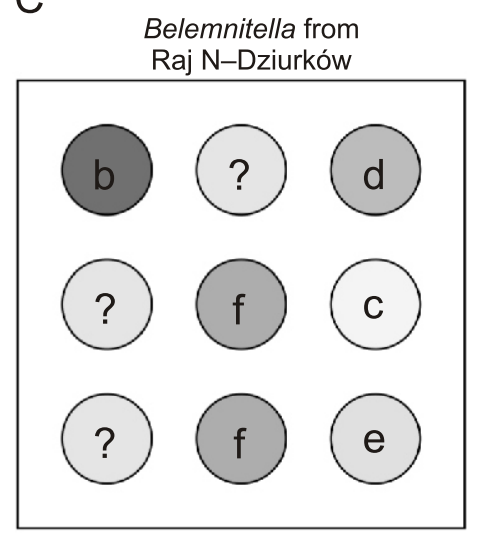

Fig. 5. Structure of the applied self organized maps

A-12 $(3 \times 4)$ neurons in the output layer with 53 guards analysed from the interval Sadkowice Szkoła-Sadkowice N (1) of the Vistula section; B - $9(3 \times 3)$ neurons in the output layer with 43 guards analysed from Raj $(2)$; C - $9(3 \times 3)$ neurons in the output layer with 22 guards analysed from Raj N-Dziurków (3) 
garded here as natural populations and verified statistically, following Remin's (2012) procedure, first applied to the genus Belemnella. Six morphogroups were revealed in exploration of the SOM within the stratigraphic samples (1) and (2), labeled a through $f$; and five morphogroups $(b, c, d, e, f)$ were revealed within stratigraphic sample (3; see Figs. 6-8). The position of particular morphogroups on the SOM indicates the level of their similarity, e.g. in the hyperspace of stratigraphic sample (1) (Fig. 5A), morphogroup $c$ is most similar to group $d$, and least similar to group $f$. Such relationships are confirmed by comparison of mean values of particular characters (Fig. 6).

All morphogroups are characterized by small confidence intervals, implying their high morphological stability. Slightly larger confidence intervals in morphogroups from stratigraphic sample (3; see Fig. 8), resulted from smaller number of analysed specimens.

Figures 6-9 show that means of particular features in morphogroups a-f differ markedly (Fig. 5 ). In most cases, statistically significant differences concern three or more characters between recognized morphogroups, allowing their easy separation.

Statistical characteristics of all morphogroups combined from all three stratigraphic samples (1-3) are shown in Figure 9. Morphogroups $f, e, b$ are characterized by large and thick guards, whereas morphogroups $a, c, d$ are represented by small and slender guards. The morphogroup $d$ seems to be most distinct and it is characterized by very large fissure angles and a very small Kongiel distance (Fig. 9).

From among six well-defined morphogroups five are assigned to known species: $b=B$. posterior, $c=B$. langei, $d=B$. najdini, $e=B$. mucronata, $f=B$. minor (referred here to $B$. minor I and B. minor II). Morphogroup a (= Belemnitella sp. a) in addition to Belemnitella sp. 1 and Belemnitella sp. 2 are left in open nomenclature (see Systematic Palaeontology).

\section{GROUPING RESULTS}

Dorotka, Leśne Chałupy, Ciszyca, Ciszyca Brodalka, Wola Pawłowska sections: specimens from these locations are classified into morphogroups $e$ and $c(=B$. mucronata and $B$. langei respectively).

Piotrawin, Pawłowice Cemetery, Pawłowice North, Sadkowice Szkoła, Sadkowice North, Raj sections: specimens from these locations are classified into morphogroups $a$, $b, c, d, e$ and $f(=$ Belemnitella sp. a, B. posterior, B. langei, $B$. najdini, $B$. mucronata and $B$. minor I respectively). In addition, a single specimen of Belemnitella sp. 1 appeared for the first time in the Sadkowice North section.

Raj North, Solec, Podole, Kłudzie South, Kłudzie North sections: the specimens are referred to morphogroups $a, b, c$, $d$, $e$ and $f(=$ Belemnitella sp. a, B. posterior, B. langei, $B$. najdini, B. mucronata and B. minor I, B. minor II, respectively). Single specimens from Raj $N$ and Podole represent Belemnitella sp. 1 and Belemnitella sp. 2.

Przedmieścia, Dziurków: specimens are classified into morphogroups $b$ and $f(=B$. posterior and $B$. minor II).

\section{NEW BELEMNITELLA ZONATION}

Based on the taxonomic study presented above, four Belemnitella zones (concurrent and interval range zones) are defined in the Upper Campanian of the Middle Vistula section (Figs. 2 and 3). The interval ranges from the Belemnitella langei
Zone to the top of Belemnitella minor II interval range Zone or $B$. najdini-B. posterior concurrent Zone; all are located in the Tercis-defined Upper Campanian.

The proposed zonations are based on both taxa commonly recognizable in Western Europe and taxa more characteristic of Eastern Europe. The scheme based on taxa characteristic of Western Europe includes three zones: B. langei, B. minor I, and B. minor II (Figs. 2 and 3). The zonation based on the Eastern European taxa is composed of the zones of $B$. langei and $B$. najdini-B. posterior. Belemnitella najdini and B. posterior are rare in Western Europe but are well represented in Central and East European successions.

The Belemnitella zonation, proposed herein, is correlated against the inoceramid and Belemnella zonations, as recently worked out (Walaszczyk, 2004; Remin, 2012, respectively; Figs. 2 and 3). Accordingly, the Campanian/Maastrichtian boundary, as defined in Tercis, corresponds to the top of the $B$. minor II or alternatively to the top of the $B$. najdini-B. posterior concurrent Zone (Figs. 2 and 3). Nearly all Belemnitella species disappear within an interval of only a few metres around this level (Fig. 2). Higher up, the only survivors belongs to $B$. ex gr. minor II/posterior and are represented by single specimens. This is also the base of the Belemnella obtusa and Belemnella vistulensis Zones (Remin, 2012), the base of which defines the base of the Maastrichtian in terms of the Belemnella clade (cf. Figs. 2 and 3). low.

Brief characteristics of the Belemnitella zones are given be-

The Belemnitella langei interval range Zone; the base of the zone is defined by the FAD of the index taxon, and its top by the simultaneous FADs of $B$. minor I, B. posterior and $B$. najdini. Only two Belemnitella species, B. langei and B. mucronata, occur in this zone. The zone corresponds to the interval embracing the Cataceramus subcompressus Zone up to the Sphaeroceramus pertenuiformis Zone.

In the Vistula section the lower boundary of the zone is not exposed (Fig. 2). Its upper boundary is placed between the Wola Pawłowska section and the base of the Pawłowice Cemetery and Piotrawin sections, which are separated by an observational gap of a few metres (Fig. 2)

The Belemnitella minor I interval range Zone; the base of the zone is defined by the FAD of the index taxon or by the FADs of $B$. najdini and $B$. posterior. Its upper boundary is defined by the FAD of $B$. minor II. Five Belemnitella species were recognized in this zone (Fig. 2). It corresponds to the "Inoceramus" altus and lower and middle parts of the "Inoceramus" inkermanensis zones.

In the Vistula section the lower boundary of the zone is not exposed. It lies somewhere below the base of the Pawłowice Cemetery and Piotrawin sections and the Wola Pawłowska section (Fig. 2). Its top is located between the Sadkowice $N$ and Raj sections, which are separated by a minute observational gap (Fig. 2).

The Belemnitella minor II interval range Zone; the base of this zone is defined by the FAD of the index taxon and its top by LADs of $B$. najdini and $B$. langei. Five Belemnitella species were recognized in this zone (Fig. 2). It corresponds to the upper part of the "Inoceramus" inkermanensis, up to the middle part of the "Inoceramus" redbirdensis zones. In terms of the Belemnella zonation, it covers the whole interval of the Belemnella lanceolata and Belemnella inflata zones (Fig. 2).

In the Vistula section the lower boundary is located in the Raj section. Its top is exposed at the "boundary marls" in the sections of Podole, Kłudzie S and Kłudzie N (Fig. 2).

The Belemnitella najdini-Belemnitella posterior concurrent range Zone; the base of the zone is defined by the 


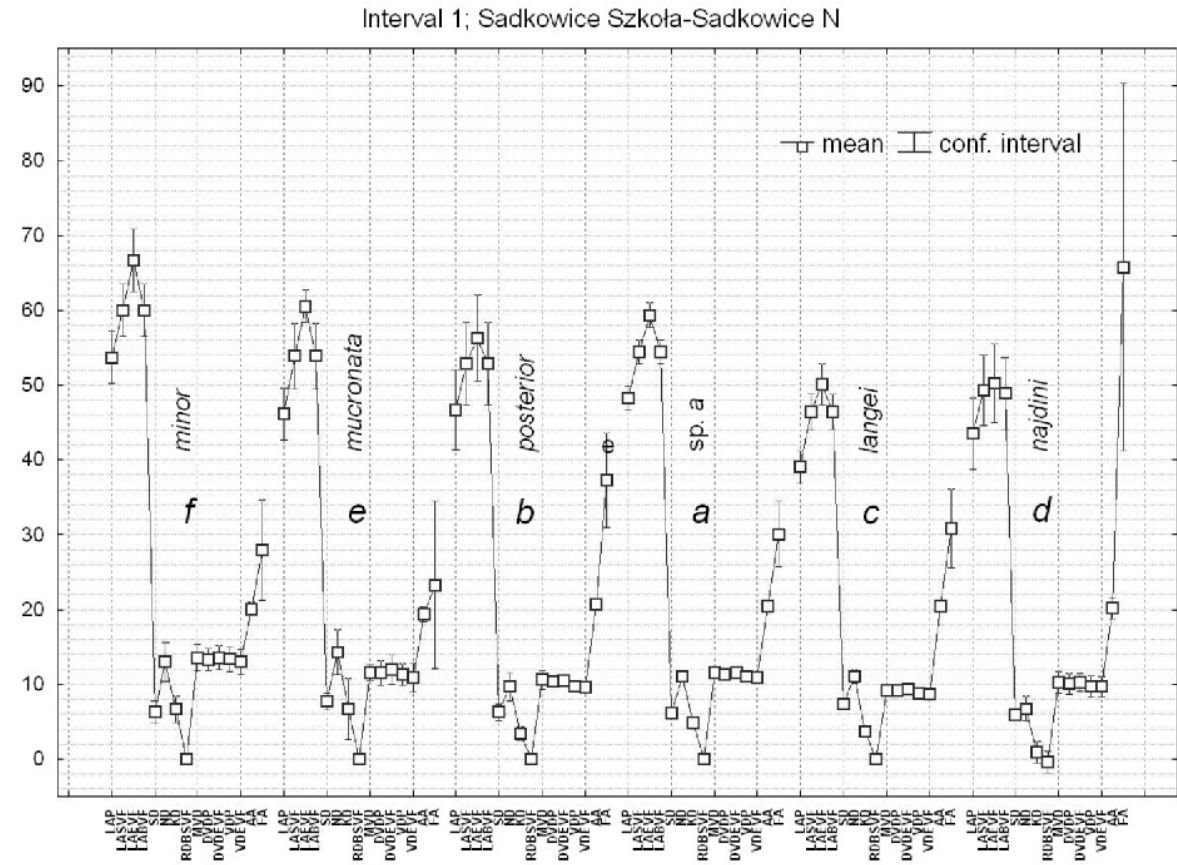

Fig. 6. Means and $95 \%$ confidence intervals of features

Groups a-f from interval (1) Sadkowice Szkoła-Sadkowice N

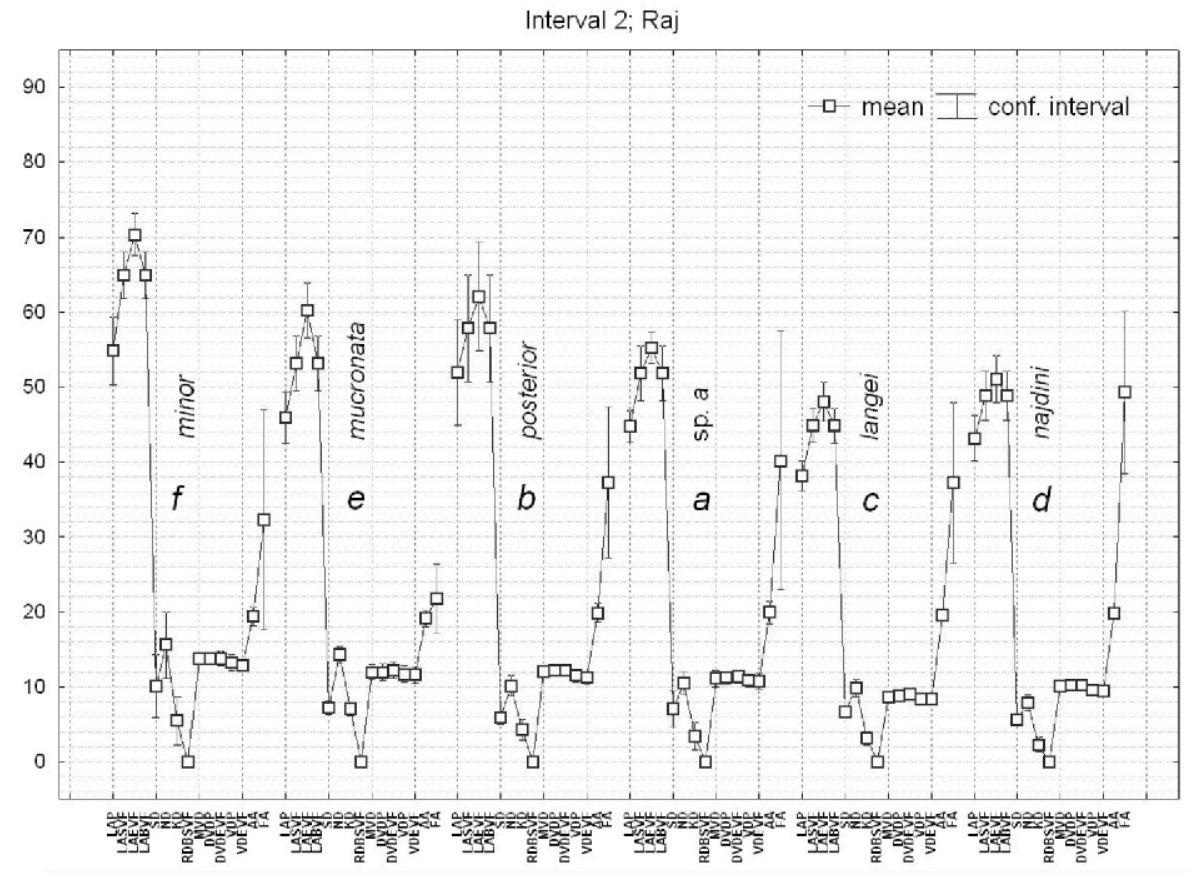

Fig. 7. Means and $95 \%$ confidence intervals of features

Groups $a-f$ from interval (2) Raj 


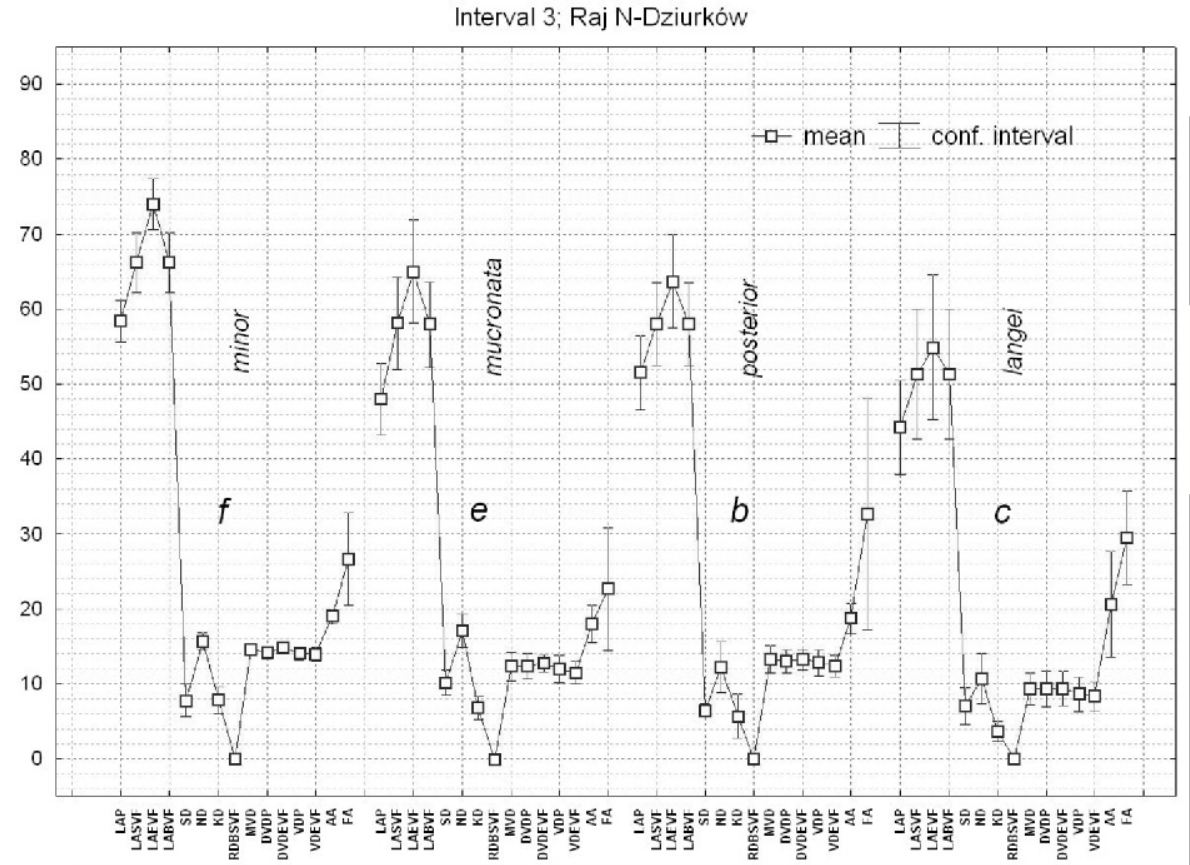

Fig. 8. Means and $95 \%$ confidence intervals of features

Groups b, c, e, f from interval (3) Raj N-Dziurków

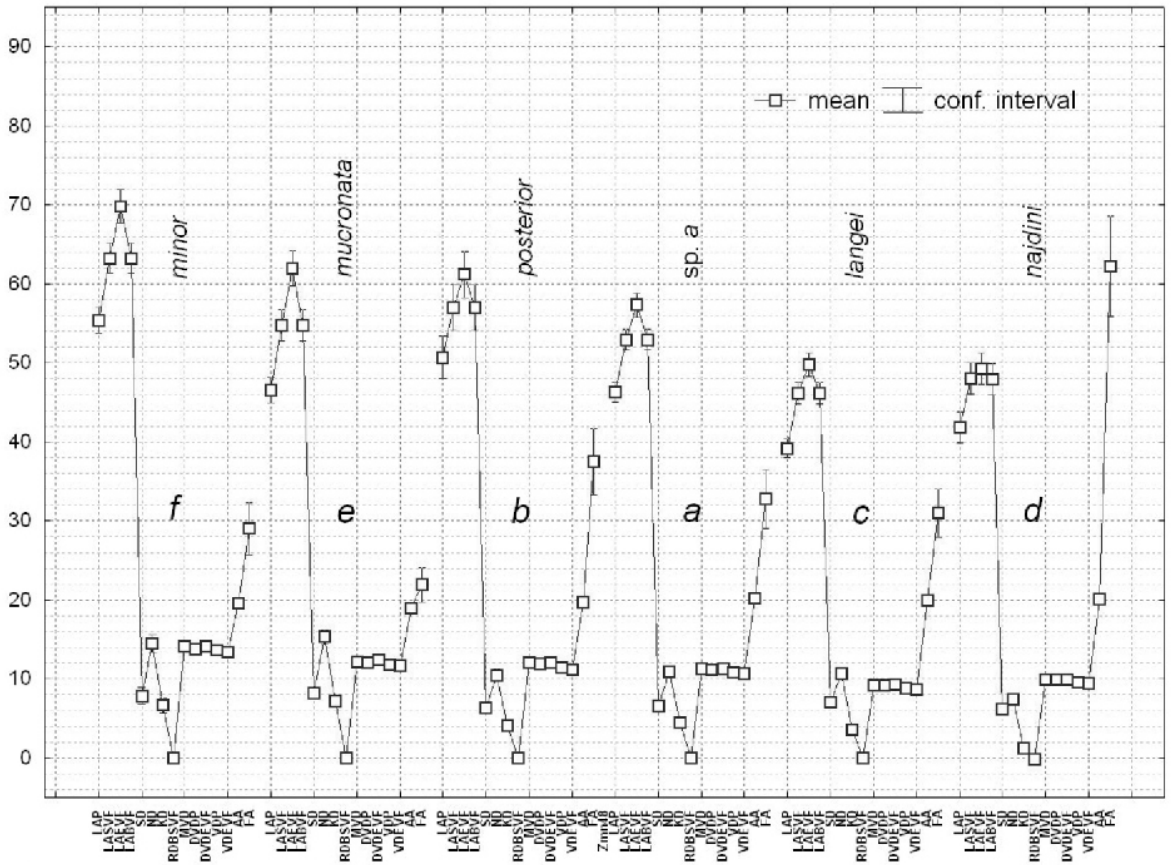

Fig. 9. Means and $95 \%$ confidence intervals of features in groups $a+a, b+b+b, c+c+c$ $d+d, e+e+e, f+f+f$ from two $(1+2)$ or three $(1+2+3)$ succeeding intervals respectively 
FAD of the index taxa or simultaneous entry of $B$. minorl. Its upper boundary is defined by the LADs of $B$. najdini and $B$. langei, which seem to disappear simultaneously. Six Belemnitella species were recognized in this zone (Fig. 2). The zone corresponds to the interval embracing "Inoceramus" altus to the middle part of the "Inoceramus" redbirdensis zones. In terms of the Belemnella zonation, the upper part of this zone corresponds to the Belemnella lanceolata and Belemnella inflata zones (Fig. 2).

In the Vistula section the lower boundary of the zone is not exposed. It lies somewhere below the base of the Pawłowice Cemetery and Piotrawin sections and the Wola Pawłowska section (Fig. 2). Its top is located at the "boundary marls" exposed in the Podole, Kłudzie S and Kłudzie N sections (Fig. 2).

\section{DISCUSSION AND CONCLUSIONS}

Four Belemnitella zones were established within the Upper Campanian and none in the Lower Maastrichtian. In the Belemnitella-based zonation, the Campanian/Maastrichtian boundary in the Middle Vistula section is placed at the top of the $B$. najdini-B. posterior and $B$. minor II zones. This boundary is represented by a distinctive lithological unit - the "boundary marls". It corresponds closely to the base of the Belemnella obtusa / Belemnella vistulensis zones (Figs. 2 and 3), the Belemnella-boundary markers (see Remin, 2012). This boundary also corresponds to the Campanian/Maastrichtian boundary in Kronsmoor, northern Germany (Niebuhr et al., 2011).

The Belemnitella zonation as worked out herein differs from zonations recognized in other European areas (Fig. 3). The main difference concerns the use of $B$. posterior and of $B$. najdini and the stratigraphic position of $B$. langei, which precedes B. minor I in the Middle Vistula section.

Surprisingly, the level around the "boundary marls" in the Vistula section, corresponding closely to the Campanian/Maastrichtian boundary, represents a critical point in the evolutionary history of both Belemnitella and Belemnella. At this level, within an interval of only a few metres, nearly all Late Campanian Belemnitella taxa disappear. The only survivors are rare $B$. ex gr. minor II/posterior. This extinction event within the Belemnitella linage corresponds to an evolutionary turnover within the genus Belemnella (cf. Remin, 2012).

The succession of taxa within the genus Belemnitella may be summarized as follows.

Belemnitella mucronata (Schlotheim, 1813) seems to be a well-defined species (Christensen et al., 1975). It is characteristic of the uppermost Lower and lowermost Upper Campanian. This species has been also noted higher in the Upper Campanian (Kongiel, 1962; Christensen, 1975, 1997a, b).

Less clear is the understanding of Belemnitella minor Jeletzky, 1951, the index species of the uppermost Campanian (see discussion in Christensen et al., 1975; Christensen, 1995). In the present paper, the author follows the interpretation of Christensen (1995, 1999), with two chronospecies, B. minor I and $B$. minor II, distinguished in the lineage. B. minor from the Vistula section is slightly smaller and is characterized by a smaller Schatzky distance than the populations of $B$. minor sensu Christensen (1995) from Norfolk. The Vistula material also differs from east European populations of the species

Belemnitella langei Jeletzky, 1948, is interpreted here in the sense of its holotype and paratypes. Statistically valid topotype material of this species is inaccessible. Various concepts of this species were discussed by Christensen (1995), who showed marked differences between B. langei sensu Jeletzky (1948), B. langei sensu Schulz (1978), and B. langei sensu Birkelund (1957). Schulz (1978) suggested that $B$. lange $i$ is an East European species, with restricted occurrences in Western Europe. Christensen (1995) did not confirm this statement, although he was able to recognize $B$. langei only on the basis of a few specimens in Norfolk (Christensen, 1995). Summarizing, there are five, largely incompatible, definitions of $B$. langei: (1) the type material from Ukraine; (2) langei sensu Birkelund from Denmark (= B. schulzi) with large range of variation; (3) langei sensu Schulz from Germany; langei sensu Christensen from Norfolk, England; and langei as understood herein, based on 38 specimens, from the Vistula section, Poland. Up to now, Christensen's concept of $B$. langei from Norfolk is commonly accepted. In this respect the material from the Vistula section differs only by smaller mean values of the fissure angle.

So far, Belemnitella najdini Kongiel, 1962 was understood only in the sense of its original diagnosis based on its holotype and paratype. The topotype population of $B$. najdini described herein (19 specimens) is statistically representative. The species has been commonly used as a marker of the uppermost Upper Campanian in Eastern Europe (e.g., Najdin, 1964a, b, 1979). Herein it is used in the zonation for the Vistula section.

B. posterior Kongiel, 1962 is understood here in the sense of its holotype and paratypes. The studied population of this species is well compatible with populations referred to as $B$. posterior by Kongiel (1962) and Christensen (1998b, unpubl. report). The topotype population studied herein is statistically representative.

As mentioned above, understanding of particular species differs for various reasons. Another complicating factor is rather poor understanding of the biological significance of such taxonomically critical characters as the Schatzky distance (SD) or the fissure angle (FA).

To omit subjectivity in selecting taxonomically critical characters, the author implemented the same taxonomic procedure for both Upper Campanian and Maastrichtian belemnite genera - Belemnitella and Belemnella. This allows the comparison of selected features in both genera and the tracking of their evolutionary changes within the whole interval studied.

\section{SYSTEMATIC PALAEONTOLOGY}

\section{CONVENTION}

The terms and measurements used to describe belemnite guards follow Christensen (1995) and Remin (2008, 2012; see Fig. 4). The following abbreviations are used: LAP - length from the apex to the protoconch; LASVF - length from the apex to the start of the bottom of the ventral fissure; SD (Schatzky distance) - distance between the mid-point of the protoconch and the start of the ventral fissure at the alveolar wall; ND (Nowak distance) - distance between the midpoint of the protoconch and the end of the bottom of the ventral fissure on the outer surface of the rostrum; KD (Kongiel distance) - distance between the start of the bottom of the ventral fissure at the alveolar wall and its end on the outer surface of the rostrum; MVD - maximal ventral diameter; DVDP - dorsoventral diameter at the protoconch; DVDEVF - dorsoventral diameter at the end of the ventral fissure; VDP - ventral diameter at the protoconch; VDEVF - ventral diameter at the end of the ventral fissure; $A A-$ alveolar angle; FA - fissure angle; and $\mathrm{BI}$ (Birkelund Index) = 
LAP/DVDP. Besides AA and FA (angles in degrees), all other measurements are in millimetres.

\section{REPOSITORIES}

The material is housed in the collections of the S.J. Thugutt Geological Museum, Faculty of Geology, at the University of Warsaw; specimens prefixed by $\mathrm{ZI} / 65 /$ abbreviations of the outcrop, e.g. ZI/65/Raj/001. The locations are shown in Figure 1; abbreviations for individual outcrops are as follows: Ciszyca Brodalka - Cisz/Broda; Ciszyca droga - Cisz/dr; Dorotka - Dor; Dziurków - Dziu; Kłudzie N - KłudzN; Kłudzie S - KłudzS; Pawłowice Cemetery - Pawł/Cm; Pawłowice Posesja Pawł/pos; Piotrawin - Piotr; Podole - Podole; Przedmieścia Przedm; Raj - Raj; Raj N - RajN; Sadkowice N - SadN; Sadkowice Szkoła - Sad/szk; Wola Pawłowska - Wola/Pawł Specimens prefixed with Mcd-are stored in the Museum of the Earth in Warsaw of the Polish Academy of Sciences.

GENERAL REMARKS

The west European Belemnitella and biostratigraphic schemes based on the genus are relatively well-known (Birkelund, 1957; Christensen, 1975-2002; Keutgen, 2011), however, their direct relationships to east European forms and biostratigraphic schemes (Jeletzky, 1941; Naidin, 1952, 1975, 1979; Nikitin, 1958; Naidin and Beniamovski, 2006; Olferev et al., 2007; Benyamovskiy et al., 2012) are far from satisfactory. From the Upper Campanian through Lower Maastrichtian more than twenty taxa (species, subspecies and variants) have been described within the genus (e.g., Jeletzky, 1941-1964; Vassilenko and Rassmyslowa, 1950; Naidin, 1952-1979; Christensen, 1975-2002; Birkelund, 1957; Nikitin, 1958; Kongiel, 1962; Schulz, 1982). The taxonomic status of many of these taxa remains uncertain (discussion in Christensen, 1988, 1993, 1996, 1997a, b).

Six morphotypes, plus two other forms, revealed by the Kohonen neural network analysis, are interpreted herein as distinct species. Five of them can be referred to established forms, while the remaining three are left in open nomenclature. Their final taxonomic interpretation requires further investigations, particularly comparison with East European material and "giant" forms of $B$. mucronata of Wood (1988) from England. The species recognized herein are subdivided into two main groups, the Belemnitella mucronata group that includes forms generally large and stout, and the Belemnitella langei group which is characterized by small and slender forms. The Belemnitella mucronata group comprises $B$. mucronata, B. minor ( $=B$. minor I and B. minor II), and B. posterior. The Belemnitella langei group comprises $B$. sp. a, B. langei and $B$. najdini. Although different in external and internal morphology, both groups are characterized by a similar evolutionary pattern within the Late Campanian and Early Maastrichtian. The forms change from generally longer and stouter to shorter and more slender.

Kongiel (1962) introduced four classes of "relative thickness" (= DVDEVF herein; see Fig. 4): I - 4.0-7.0 mm; II 7.5-10.5 mm; III - 11.0-14.0 mm; IV - 14.5-17.5 mm, however, this classification has not been used by other authors.

Christensen (1995) proposed a classification of relative length of species of Belemnitella based on the Birkelund Index (BI = LAP/DVDP): (1) $\mathrm{BI}<4$ guard stout, (2) BI 4-5 guard slender, (3) $\mathrm{BI}>5$ guard very slender. It is worthy of note that "relative length" sensu Christensen (1995) is not equal to "relative length" sensu Kongiel (1962) or other East European researchers. For Christensen, it is the elongation (slenderness), whereas, e.g. for Kongiel, it is the length from apex to the start of the ventral fissure on the outer surface of the guard (= LAEVF herein; see Fig. 4). Christensen (1995) introduced a classification of size-ranges of species of Belemnitella based on length from apex to protoconch (LAP): (1) guard small LAP <55 mm; (2) guard large LAP 55-65 mm; (3) guard very large LAP $>65 \mathrm{~mm}$. However, such length-ranges cause marked disproportion between small, large and very large guards. According to it, most belemnites are characterized by small, eventually medium-size guards.

For these reasons, it was essential to propose a more balanced classification of size-ranges based on length form the apex to the protoconch (LAP) or length from the apex to the end of ventral fissure (LAEVF). The latter length seems to be better for two reasons: (1) when LAEVF is measurable, it allows all other features to be measured; (2) this length is easy to measure even during the fieldwork and does not require splitting of the guard. The biometric characteristics presented herein are based on complete specimens from the Vistula section. The

Table 1

Ranges of size categories of selected external and internal features

\begin{tabular}{|l|c|c|c|c|}
\hline \multirow{2}{*}{} & \multicolumn{4}{|c|}{ Size } \\
\cline { 2 - 5 } & small & medium & large & very large \\
\hline \multicolumn{5}{|c|}{ diameters } \\
\hline LAEVF & $<55 \mathrm{~mm}$ & $55-65 \mathrm{~mm}$ & $65-75 \mathrm{~mm}$ & $>75 \mathrm{~mm}$ \\
\hline LAP & $<45 \mathrm{~mm}$ & $45-55 \mathrm{~mm}$ & $55-65 \mathrm{~mm}$ & $>65 \mathrm{~mm}$ \\
\hline \multicolumn{5}{|c|}{ internal features } \\
\hline MVD & $<10 \mathrm{~mm}$ & $10-12 \mathrm{~mm}$ & $12-14 \mathrm{~mm}$ & $>14 \mathrm{~mm}$ \\
\hline DVDP & $<10 \mathrm{~mm}$ & $10-12 \mathrm{~mm}$ & $12-14 \mathrm{~mm}$ & $>14 \mathrm{~mm}$ \\
\hline VDP & $<10 \mathrm{~mm}$ & $10-12 \mathrm{~mm}$ & $12-14 \mathrm{~mm}$ & $>14 \mathrm{~mm}$ \\
\hline \multicolumn{5}{|c|}{} \\
\hline SD & $<7 \mathrm{~mm}$ & $7-9 \mathrm{~mm}$ & $9-11 \mathrm{~mm}$ & $>11 \mathrm{~mm}$ \\
\hline ND & $<9 \mathrm{~mm}$ & $9-12 \mathrm{~mm}$ & $12-15 \mathrm{~mm}$ & $>15 \mathrm{~mm}$ \\
\hline KD & $<3 \mathrm{~mm}$ & $3-5 \mathrm{~mm}$ & $5-7 \mathrm{~mm}$ & $>7 \mathrm{~mm}$ \\
\hline AA & $<19^{\circ}$ & $19-21^{\circ}$ & $21-22^{\circ}$ & $>22^{\circ}$ \\
\hline FA & $<25^{\circ}$ & $25-40^{\circ}$ & $40-60^{\circ}$ & $>60^{\circ}$ \\
\hline
\end{tabular}

The descriptive terms are shown in Figure 4

adopted size-ranges of selected parameters characterizing particular Belemnitella species are summarized in Table 1.

Family Belemnitellidae Pavlow, 1914

Genus Belemnitella d'Orbigny, 1840

(ICZN 1985, Opinion 1328; name no. 2269)

T y p e s p e c i e s. - Belemnites mucronatus Schlotheim, 1813: 111, by subsequent designation of Herrmannsen (1846: 105); ICZN Opinion 1328 (1985), name no. 2979 (cf. discussion by Christensen et al., 1973, 1975, 1982; Christensen, 1975, 1995).

D i a g n o s i s. - Small, medium to large belemnitellids (max. LAP up to $80 \mathrm{~mm}$ ) with a deep, cone-shaped alveolus. The guard is usually flattened ventrally. Alveolus connected with the surface of the guard through long ventral fissure. The bottom of the ventral fissure is variable. Alveolar angle (AA) varies between 17 and $24^{\circ}$ and is rather constant within the genus. 
The ornamentation consists of variably developed dorso-lateral longitudinal depressions and dorso-lateral straight double furrows, in addition to single lateral furrows. Vascular imprints relatively well developed, especially in larger specimens. Sometimes longitudinal striae are present on the ventral side of the guard. The vascular imprints branch off the dorso-lateral double furrows posteriorly under an angle $<30^{\circ}$. Schatzky distance (SD) relatively long, usually $>4 \mathrm{~mm}$, commonly between $6-10 \mathrm{~mm}$; sometimes larger, up to $16 \mathrm{~mm}$. The relationship of LAP and DVDP is isometric (Fig. 10).

$\mathrm{O}$ c c u r r e n c e. - The genus Belemnitella is known from the Lower Santonian up to the uppermost Maastrichtian. The representatives of Belemnitella are widely distributed in the North European Province, North American Province and are also known form the northern peripheries of the Tethyan Realm.

\section{Belemnitella mucronata group}

R e m a r ks. - This group includes species of different size, stout or slender with small to medium fissure angles. The bottom of the ventral fissure is rather straight and the Schatzky distance is small, medium and only in some cases large.

Kongiel (1962) included in the group B. mucronata and $B$. posterior. Christensen's concept of the $B$. mucronata group is different. Besides these two species he included also $B$. minor I and $B$. minor II, both sensu Christensen, B. woodi Christensen, 1995, B. schulzi Christensen, 2000, and B. carlsbergensis Christensen, 1998.

Christensen (1995) described B. pauli, a transitional form between the $B$. mucronata group and the $B$. langei group.
The following species are included in the group in the present paper: B. mucronata, B. minor I and B. minor II, both sensu Christensen, B. woodi, B. pauli and B. misburgensis, 2000 and $B$. posterior. Belemnitella minor, as understood herein, differs from the nominate species of Christensen, in being smaller and having smaller Schatzky distances. B. woodi, B. pauli and $B$. misburgensis, are understood according to Christensen (1995).

Belemnitella mucronata (Schlotheim, 1813) (Fig. 11A-N)

1813. Belemnites mucronatus Schlotheim: 111 (after Christensen, 1995).

pars 1975. Belemnitella mucronata (Schlotheim); Christensen: 52-56.

pars 1975a. Belemnitella mucronata (Schlotheim); Christensen et al.: $27-57$.

pars 1995. Belemnitella mucronata (Schlotheim); Christensen: 46-49.

pars 1999. Belemnitella mucronata (Schlotheim); Christensen: 110-112.

pars 2000b. Belemnitella mucronata (Schlotheim); Christensen: 156.

$\mathrm{N}$ e o t y $\mathrm{p}$ e. - Specimen no. kca $5 / 2$, from the middle part of the basiplana-spiniger Zone (lower Upper Campanian) of the Germania IV pit near Hannover, Germany, designated by ICZN 1985 (Opinion 1328); described and figured by Christensen et al. (1975: pl. 1 fig. 1).

$\mathrm{M}$ a t e rial. - 24 specimens from the Vistula section: Dor/001, Dor/004, Cisz/dr/002, Cisz/broda/008, Cisz/broda/014, Pawl/pos/006, Sad/szk/035, SadN/004, SadN/014, SadN/016, Piot/001, Piot/018, Raj/031, Raj/045,

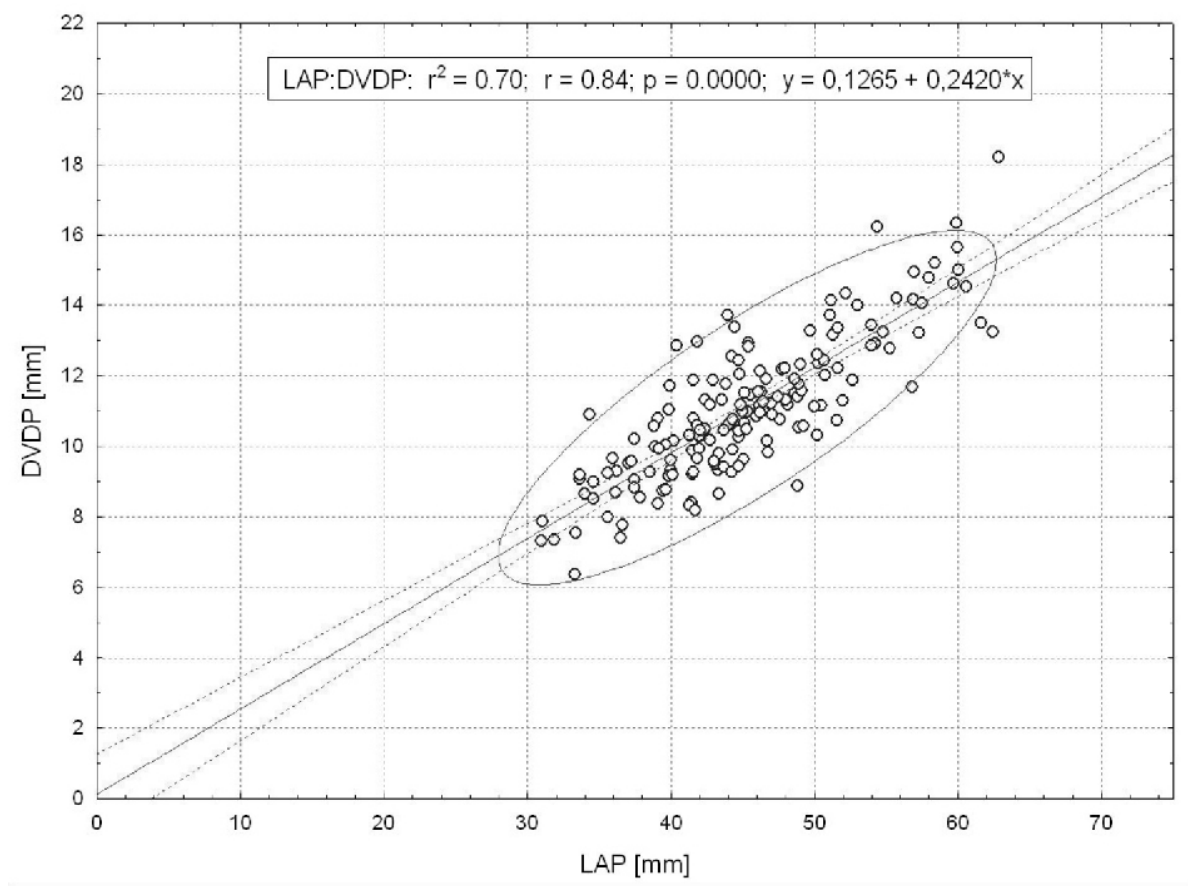

Fig. 10. Scatter diagram, regression and $95 \%(\alpha=0.05)$ confidence interval of the regression line; relationship of LAP and DVDP for all analysed specimens of the genus Belemnitella from the Vistula section 


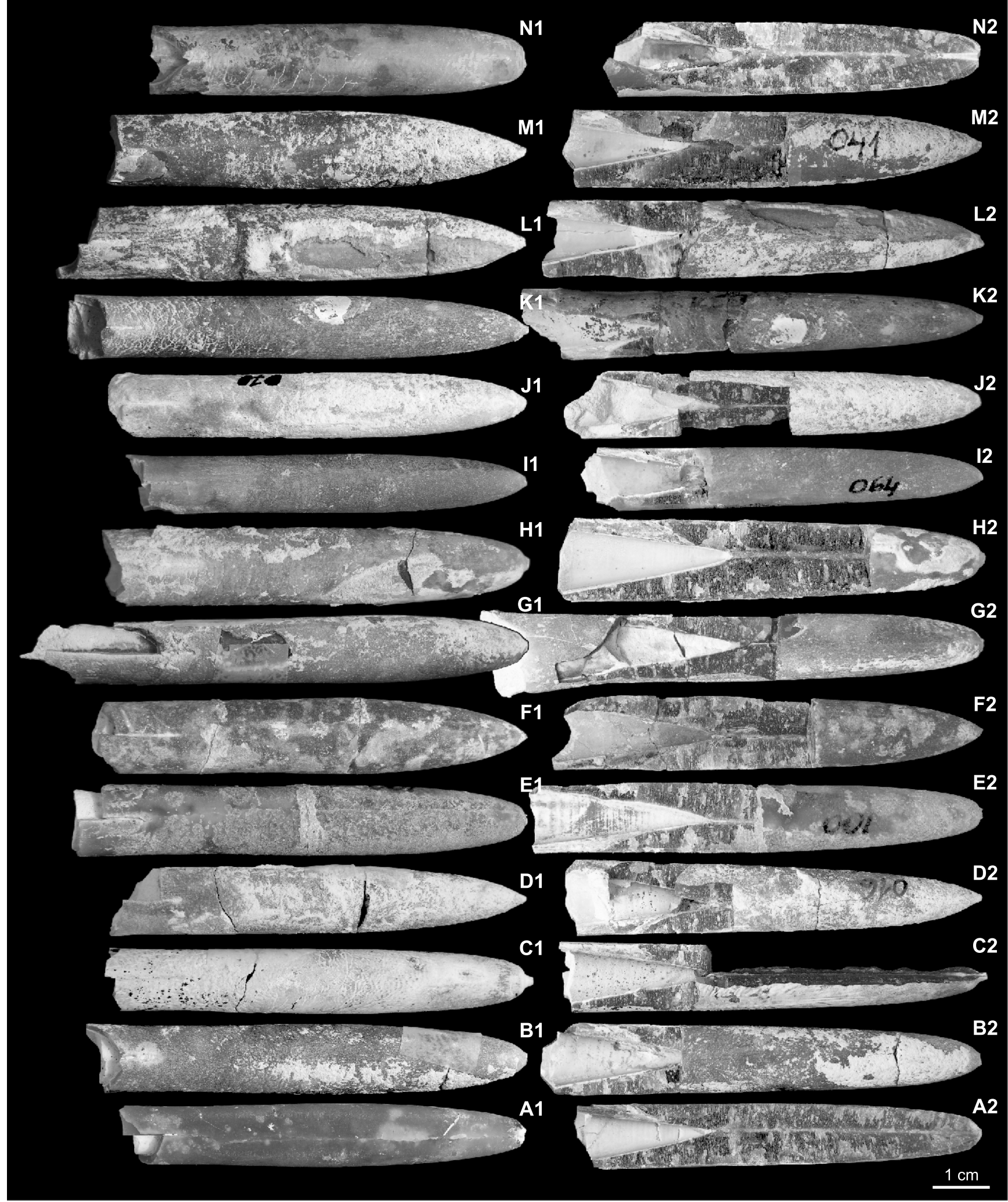

Fig. 11. Belemnitella mucronata (Schlotheim, 1813)

A - Sad/szk/035, Sadkowice Szkoła section; B-D - B - SadN/004, C - SadN/014, D - SadN/016, Sadkowice N section; E, F - E - Piot/001, F - Piot/018, Piotrawin section; G-J - G - Raj/031, H - Raj/046, I - Raj/064, J - Raj/070, Raj section; K-N - K - RajN/031, L - RajN/034, M RajN/041, N - RajN/045, Raj N section; 1 - ventral view; 2 - dorso-ventral view and the inner structure of the guard 
Raj/046, Raj/055, Raj/064, Raj/070, RajN/031, RajN/034, RajN/041, RajN/047, Podole/006.

D e s c r i p t i o n. - Guard medium to large, stout to moderately slender (mean LAEVF $=62 \mathrm{~mm}$; $\max$ LAEVF up to $69.5 \mathrm{~mm}$ ); LAP medium (mean LAP $=46.6 \mathrm{~mm}$; max. LAP up to $51.6 \mathrm{~mm}$ ); guard generally subcylindrical in ventral view and subconical to conical in lateral view, markedly flattened ventrally over its entire length; DVDP slightly larger than VDP. Mean value of Birkelund Index $\mathrm{BI}=3.9$ with an observed range 3.20-4.79. Apical end moderately obtuse to acute, usually with well defined mucro.

$\mathrm{SD}$ medium to large (mean $=8.2 \mathrm{~mm}$ ); $\mathrm{ND}$ and $\mathrm{KD}$ very large with mean values of 15.4 and $7.2 \mathrm{~mm}$, respectively, significantly larger than in other forms of Belemnitella from the studied interval; FA small ( mean $=22^{\circ}$ ), smallest among the studied representatives of the genus Belemnitella (Fig. 9); AA small to medium $\left(\right.$ mean $\left.=19^{\circ}\right)$. Shape of bottom of ventral fissure usually straight.

Well-developed dorso-lateral longitudinal depressions continue posteriorly in dorso-lateral double-furrows. Vascular markings well defined especially in large specimens, mainly on ventral and lateral side; longitudinal striae present sometimes. The complete biometry of Belemnitella mucronata (morphogroup e) is summarized in Table 2.

$\mathrm{R}$ e $\mathrm{m}$ a r k s. - The specimens with complete biometry of morphogroup e were compared with the topotype population of B. mucronata from the Germania IV Quarry, the type locality for the neotype of $B$. mucronata (cf. Christensen et al., 1975). The analysis revealed that morphogroup $e$ is characterized by only slightly larger values of LAP and slightly smaller values of DVDP, albeit these differences are very small. This is expressed by different $\mathrm{BI}$ values. The study population is slender (mean $\mathrm{BI}=3.9$ ) in comparison to the topotype population which is characterized by smaller $\mathrm{BI}$ values (mean $\mathrm{BI}=3.4$ ), although this could be related to simple environmental variability than to real species diversity. All other features do not show any significant differences (cf. Christensen et al., 1975). Consequently, I interpret morphogroup e as representing $B$. mucronata.
Form B. minor, B. mucronata differs by markedly smaller length-features, diameters and FA (Fig. 9).

B. mucronata differs from $B$. posterior by slightly smaller length-features and significantly larger ND and KD (Fig. 9). It is also characterized by a markedly smaller FA (mean $=21.6^{\circ}$ ) than $B$. posterior $\left(\right.$ mean $\left.=37.5^{\circ}\right)$.

From Belemnitella sp. a and B. langei, B. mucronata differs by significantly larger length-features, all diameters as well as SD, ND and KD (Fig. 9). Additionally B. mucronata has a significantly smaller FA (mean $\left.=21.6^{\circ}\right)$ than observed in Belemnitella sp. $a\left(\right.$ mean $\left.=32 \cdot 8^{\circ}\right)$ and $B$. langei $\left(\right.$ mean $\left.=31^{\circ}\right)$.

The comparison of $B$. najdini and $B$. mucronata show that length-features, all diameters as well as SD, ND and KD are significantly different and are larger in B. mucronata (Fig. 9). In contrast, $B$. najdini is characterized by a very large FA (mean = $\left.62.2^{\circ}\right)$.

O c c u r r e n c e. - In the Vistula section, B. mucronata is known form the Upper Campanian (according to the Tercis definition) and was recorded from: Dorotka, Ciszyca Brodalka, Pawłowice Cemetery, Pawłowice Posesja, Sadkowice Szkoła, Sadkowice N, Raj, Raj N and Podole. It is known form the North European Province and the northern part of the Tethyan Realm.

Belemnitella minor Jeletzky, 1951

(= B. minor I Jeletzky, 1951 and B. minor II Christensen, 1995) (Fig. 12A-L)

1853. Belemnitella mucronata (Schlotheim); Sharpe: 6, pl. 1, fig. 2 (non figs. 1, 3; after Christensen, 1995).

1951a. Belemnitella mucronata mut. minor Jeletzky: 203.

1951b. Belemnitella mucronata mut. minor Jeletzky; Jeletzky: 87 , pl. 1, fig. 3.

pars1975. Belemnitella minor Jeletzky; Christensen: 56-58. pars1995. Belemnitella minor I Jeletzky; Christensen: 55-64. pars1995. Belemnitella minor II Christensen: 64-69.

Biometry and descriptive statistics of the Belemnitella mucronata (= morphogroup e)

\begin{tabular}{|l|c|c|c|c|c|c|c|c|c|c|}
\hline $\begin{array}{c}\text { Variables } \\
{\left[\begin{array}{l}{ }^{*} \text { inm] } \\
{\left[{ }^{\circ}\right]}\end{array}\right.}\end{array}$ & $n$ & Mean & $\begin{array}{c}\text { Confidential } \\
\text { interval: } \\
-95 \%\end{array}$ & $\begin{array}{c}\text { Confidential } \\
\text { interval: } \\
+95 \%\end{array}$ & Median & Minimum & Maximum & Variance & $\begin{array}{c}\text { Standard } \\
\text { Deviation }\end{array}$ & $\begin{array}{c}\text { Standard } \\
\text { Error }\end{array}$ \\
\hline LAP & 19 & 46.60 & 44.97 & 48.23 & 46.22 & 39.83 & 51.63 & 11.44 & 3.383 & 0.776 \\
\hline LASVF & 19 & 54.79 & 52.80 & 56.77 & 54.27 & 46.90 & 62.80 & 16.89 & 4.109 & 0.943 \\
\hline LAEVF & 19 & 61.97 & 59.78 & 64.16 & 61.30 & 52.95 & 69.53 & 20.60 & 4.539 & 1.041 \\
\hline LABVF & 19 & 54.75 & 52.80 & 56.69 & 54.27 & 46.90 & 62.09 & 16.28 & 4.035 & 0.926 \\
\hline SD & 19 & 8.18 & 7.49 & 8.87 & 8.00 & 5.92 & 11.71 & 2.07 & 1.438 & 0.330 \\
\hline ND & 19 & 15.36 & 14.43 & 16.30 & 15.22 & 12.44 & 20.05 & 3.76 & 1.940 & 0.445 \\
\hline KD & 19 & 7.18 & 6.55 & 7.81 & 7.03 & 5.47 & 10.79 & 1.71 & 1.308 & 0.300 \\
\hline RDBSVF & 19 & -0.04 & -0.12 & 0.04 & 0.00 & -0.71 & 0.00 & 0.03 & 0.163 & 0.037 \\
\hline MVD & 19 & 12.17 & 11.68 & 12.66 & 12.08 & 10.45 & 13.80 & 1.05 & 1.026 & 0.235 \\
\hline DVDP & 19 & 12.06 & 11.58 & 12.53 & 12.06 & 10.45 & 13.74 & 0.98 & 0.988 & 0.227 \\
\hline DVDEVF & 19 & 12.45 & 12.01 & 12.89 & 12.41 & 10.67 & 14.17 & 0.83 & 0.914 & 0.210 \\
\hline VDP & 19 & 11.82 & 11.34 & 12.30 & 11.76 & 10.09 & 13.52 & 1.00 & 0.998 & 0.229 \\
\hline VDEVF & 19 & 11.61 & 11.14 & 12.08 & 11.41 & 10.13 & 13.69 & 0.97 & 0.984 & 0.226 \\
\hline AA ${ }^{*}$ & 19 & 18.99 & 18.45 & 19.52 & 19.31 & 16.42 & 20.90 & 1.25 & 1.117 & 0.256 \\
\hline FA & 19 & 21.96 & 19.78 & 24.13 & 21.29 & 13.90 & 29.12 & 20.33 & 4.509 & 1.034 \\
\hline
\end{tabular}




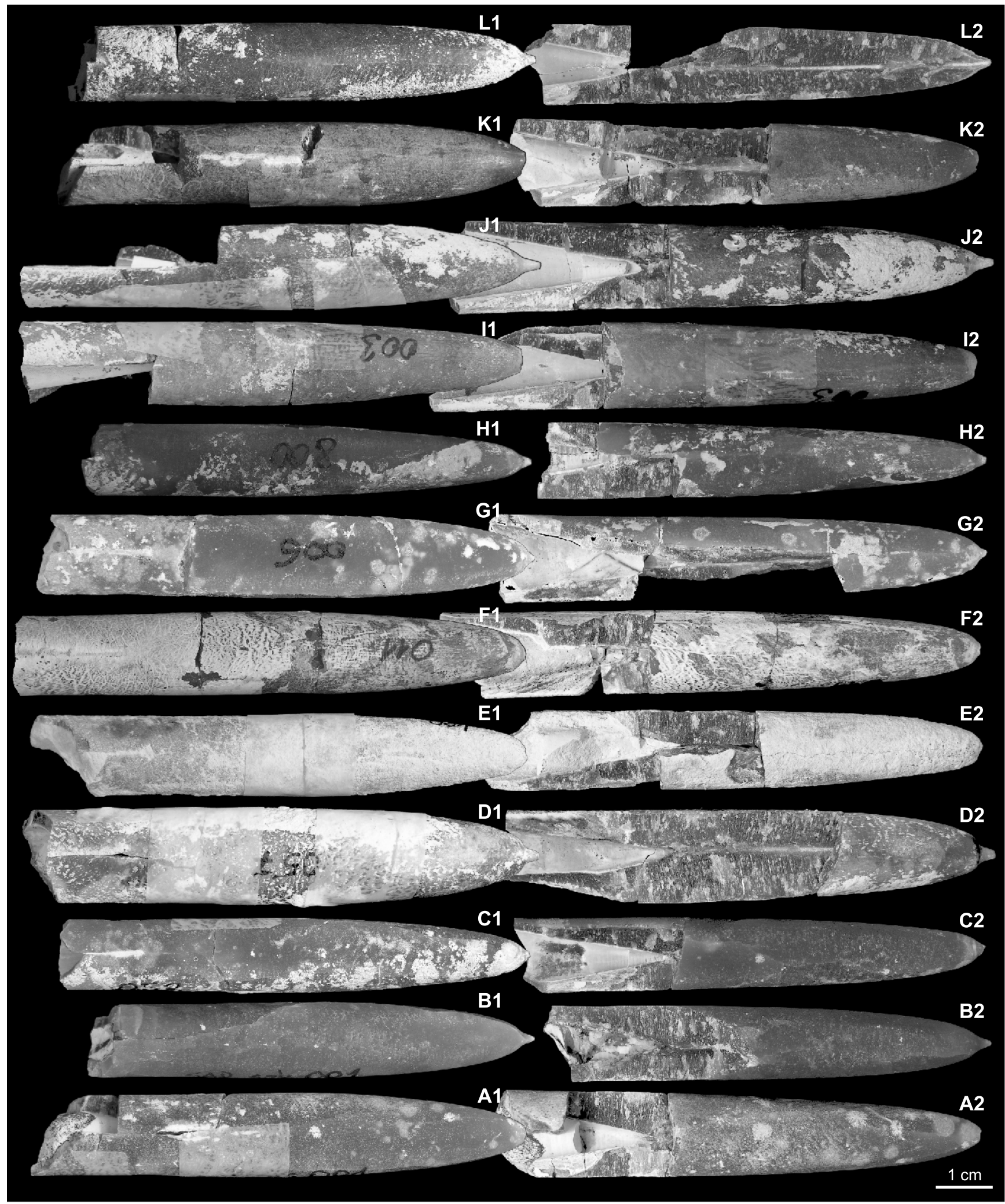

Fig. 12. Belemnitella minor

Belemnitella minor I Jeletzky, 1951: A - Pawł/pos/001, Pawłowice Posesja section; B-E: B -Sad/szk/001, C - Sad/szk/053, D Sad/szk/057, E - Sad/szk/064, Sadkowice Szkoła section; F - SadN/011, Sadkowice N section; Belemnitella minor II Christensen, 1995: G Piot/006, Piotrawin section; H - Raj/006, Raj section; I-L: I - RajN/003, J - RajN/005, K - RajN/038, L - RajN/062, Raj N section; other explanations as in Figure 11 
pars1999. Belemnitella minor I Jeletzky; Christensen: 113-114. pars1999. Belemnitella minor II Christensen: 114-118.

G e n e r a I r e m a r k s. - The concept of $B$. minor based on its original diagnosis, used by the East European researchers (e.g., Jeletzky, 1951a, b; Naidin, 1952; Kongiel, 1962) is not identical with the concept of Christensen (1995) based on the holotype and followed recently in West Europe (Christensen, 1995, 1999; Keutgen and Jagt, 1999; Keutgen et al., 2010; Jagt, 2012). According to the original diagnosis of Jeletzky (1951a), B. minor differs form B. mucronata by its smaller guard and diameter and markedly larger fissure angle.

Christensen (1995) distinguished three chronospecies within the lineage of $B$. minor. B. minor I, B. minor II and B. minor III. The latter was included in the synonymy of $B$. minor II (Christensen, 1999). B. minor from the Middle Vistula section shows a similar developmental trend through its stratigraphic range when compared to subspecies of $B$. minor recognized in Norfolk and the Mons region in Belgium. Consequently, two stratigraphic forms are distinguished: B. minor I Jeletzky, 1951 and B. minor II Christensen, 1995. B. minor from the Middle Vistula section is slightly smaller and has a generally smaller $\mathrm{SD}$. The taxonomic description is limited to the nominate species (= B. minor) where differences between the two subspecies are stressed.

T y p e. - The holotype (BGS GSM 7747), by original designation, is the original of Sharp (1853: pl. 1; fig. 2) from the Upper Campanian, near Norwich, Norfolk; it was refigured by Jeletzky (1951a: pl. 1, fig. 3) and Christensen (1995: pl. 1, figs. 4-7; pl. 4, fig. 5).

M a t e r i a I. - 20 specimens form MVVS: Pawl/pos/001, Sad/szk/001, Sad/szk/023, Sad/szk/053, Sad/szk/057, Sad/szk/062, Sad/szk/064, SadN/002, SadN/011, Piot/006, Raj/006, Raj/057, Raj/058, Raj/066, RajN/003, RajN/005, RajN/038, RajN/062, KłudzN/006, Dziu/019.

D e s c ription. - Guard large to very large, stout to moderately slender (mean LAEVF $=69.9 \mathrm{~mm}$; max LAEVF up to $78.0 \mathrm{~mm}$ ); LAP medium to very large (mean LAP = $55.4 \mathrm{~mm}$; max. LAP up to $61.6 \mathrm{~mm}$ ); the guard generally subcylindrical in ventral view and subconical to high conical in lateral view and markedly flattened ventrally over its entire length; DVDP slightly larger than VDP. Mean value of Birkelund Index $=4.0$ with an observed range 3.35-4.56. Apical end more or less obtuse, sometimes moderately acute, usually with well-defined mucro.

$\mathrm{SD}$ medium to large (mean $=7.8 \mathrm{~mm}$ ); $\mathrm{ND}$ and $\mathrm{KD}$ large to very large with mean values of $14.5 \mathrm{~mm}$ and $6.6 \mathrm{~mm}$ respectively. SD, ND, KD are in most cases larger than in other forms of Belemnitella from the study interval. FA medium (mean = $\left.29^{\circ}\right)$; AA medium $\left(\right.$ mean $=19 \cdot 6^{\circ}$ ). Shape of bottom of ventral fissure usually straight and only sometimes slightly curved or undulating.

Dorso-lateral longitudinal depressions and dorso-lateral double-furrows usually well-developed. Vascular markings well-defined, mainly on ventral and lateral side; some specimens with pseudogranulation on ventral side; longitudinal striae present on posterior dorsal side. The complete biometric characteristics of Belemnitella minor (morphogroup f) are summarized in Table 3.

R e m a r k s. - Jeletzky (1950) recognized three types of variation within a species. One of it is a mutation, applied to chronological subspecies. B. minor was established by Jeletzky (1951a) as B. mucronata mut. minor. This taxon, sensu Jeletzky differs from B. mucronata mut. senior Nowak, 1913 (= B. mucronata mucronata; compare Birkelund, 1957; Christensen, 1986, 1995) in its smaller guard and diameters, lager fissure angle, irregular bottom of ventral fissure and being less conical in lateral view. Thus, according to Jeletzky (1950), $B$. minor is more slender and a stratigraphically younger subspecies (mutant) of B. mucronata mucronata. A specimen figured as $B$. mucronata by Sharpe (1853: pl. 1 fig. 2) was designated by Jeletzky (1951a) as the holotype of $B$. mucronata mut. minor.

For 25 years, since Jeletzky (1951) designated his new subspecies (mutant), this taxon has been used as an index fossil of the lower part of the Upper Campanian. However, when establishing his new subspecies, Jeletzky (1951) did not split the holotype to verify its internal characters. Nevertheless, he reported them in the original diagnosis of $B$. minor. This inaccuracy has been the reason why $B$. minor has been interpreted dif-

Biometry and descriptive statistics of the Belemnitella minor (= morphogroup $f$ )

\begin{tabular}{|l|c|c|c|c|c|c|c|c|c|c|}
\hline $\begin{array}{c}\text { Variables } \\
{\left[\begin{array}{l}{[\mathrm{mm}]} \\
{ }^{*} \text { in }\left[{ }^{\circ}\right]\end{array}\right.}\end{array}$ & $n$ & Mean & $\begin{array}{c}\text { Confidential } \\
\text { interval: } \\
-95 \%\end{array}$ & $\begin{array}{c}\text { Confidential } \\
\text { interval: } \\
+95 \%\end{array}$ & Median & Minimum & Maximum & Variance & $\begin{array}{c}\text { Standard } \\
\text { Deviation }\end{array}$ & $\begin{array}{c}\text { Standard } \\
\text { Error }\end{array}$ \\
\hline LAP & 20 & 55.38 & 53.71 & 57.05 & 54.97 & 49.07 & 61.57 & 12.69 & 3.562 & 0.797 \\
\hline LASVF & 20 & 63.22 & 61.30 & 65.14 & 63.48 & 54.60 & 71.13 & 16.79 & 4.098 & 0.916 \\
\hline LAEVF & 20 & 69.86 & 67.71 & 72.01 & 70.15 & 58.65 & 77.98 & 21.15 & 4.599 & 1.028 \\
\hline LABVF & 20 & 63.22 & 61.30 & 65.14 & 63.48 & 54.60 & 71.13 & 16.79 & 4.098 & 0.916 \\
\hline SD & 20 & 7.84 & 6.79 & 8.89 & 7.83 & 4.06 & 12.60 & 5.02 & 2.240 & 0.501 \\
\hline ND & 20 & 14.48 & 13.35 & 15.61 & 14.99 & 9.57 & 18.66 & 5.82 & 2.413 & 0.540 \\
\hline KD & 20 & 6.64 & 5.73 & 7.54 & 6.75 & 3.07 & 9.77 & 3.74 & 1.935 & 0.433 \\
\hline RDBSVF & 20 & 0.00 & - & - & 0.00 & 0.00 & 0.00 & 0.00 & 0.000 & 0.000 \\
\hline MVD & 20 & 14.09 & 13.52 & 14.67 & 14.05 & 11.73 & 17.17 & 1.51 & 1.229 & 0.275 \\
\hline DVDP & 20 & 13.82 & 13.30 & 14.33 & 14.04 & 11.59 & 16.23 & 1.23 & 1.109 & 0.248 \\
\hline DVDEVF & 20 & 14.14 & 13.55 & 14.73 & 14.23 & 11.47 & 16.93 & 1.57 & 1.254 & 0.280 \\
\hline VDP & 20 & 13.66 & 13.09 & 14.22 & 13.78 & 11.70 & 16.90 & 1.48 & 1.216 & 0.272 \\
\hline VDEVF & 20 & 13.40 & 12.81 & 14.00 & 13.28 & 11.22 & 16.61 & 1.59 & 1.262 & 0.282 \\
\hline AA ${ }^{*}$ & 20 & 19.59 & 19.13 & 20.04 & 19.60 & 17.48 & 21.03 & 0.93 & 0.966 & 0.216 \\
\hline FA & 20 & 28.98 & 25.72 & 32.25 & 27.74 & 15.88 & 44.22 & 48.75 & 6.982 & 1.561 \\
\hline
\end{tabular}


ferently by a number of authors. Birkelund (1957) as well as Kongiel (1962) placed $B$. minor into the synonymy of $B$. langei. Naidin (1964a, b) recognized $B$. minor together with $B$. najdini as subspecies of $B$. langei. Finally, in 1975 C.J. Wood split the holotype of B. minor (cf. Christensen, 1975; Christensen et al., 1975). It turned out that the internal characters did not agree with the original diagnosis and, as a consequence, the legitimacy of $B$. minor was questioned.

Based on the biometric data, it was reported (Christensen, 1975; Christensen et al., 1975) that the holotype of B. minor in most of its characters falls within the variability range of the topotype population of $B$. mucronata, although the stratum typicum of $B$. minor was placed stratigraphically much higher (Christensen et al., 1975). Later it was found, however (Christensen, 1995), that $B$. minor, based on the concept of its holotype (non original diagnosis) corresponded to $B$. mucronata sensu Jeletzky (1964) and to very large specimens of B. mucronata sensu Wood (1988).

Christensen (1975), based on the concept of the holotype, recognized a homogeneous population of $B$. minor from Balsvik and Bjarnum from the basal Maastrichtian (Belemnella lanceolata Zone). However, later it turned out that, based on the same material from the basal Maastrichtian, Christensen (1998a) recognized this population as representing a new species: Belemnitella carlsbergensis Christensen, 1998. This shows how the understanding of this species changed through time. Additionally, it shows that the analyses of topotype populations of B. minor (performed by Christensen in 1995) were necessary to correctly understand other so far described populations of Belemnitella minor (e.g., those from Balsvik and Bjarnum). Such variable interpretations of $B$. minor might raise doubts concerning the homogeneity of other populations of minor. All these data shows that the consensus of what should be understood under the name of $B$. minor is still open to discussion.

Nevertheless, the specimens with complete biometry of morphogroup $f$ best correspond biometrically to populations commonly described as B. minor sensu Christensen (e.g. 1995, 1999). Additionally, within the stratigraphic range of the herein recognized population of morphogroup $f$ two succeeding stratigraphic forms are distinguished, representing $B$. minor and B. minor II (cf. Christensen, 1995, 1999). The comparison of the means of particular features of older $(=B$. minor I) and younger $(=B$. minor $\mathrm{II})$ representatives of $B$. minor shows that, through the stratigraphic range of this form, guards tend to be longer with increasing values of the Schatzky distance, Nowak distance and Kongiel distance (cf. Fig. 13).

It is worthy of note, that the specimens of $B$. minor from the succeeding intervals of the Middle Vistula section (Fig. 13) are smaller and have a smaller Schatzky distance than typical populations of B. minor, e.g. from Norfolk (Christensen, 1995, 1999). However, the development pattern through time is very similar and the stratigraphic forms recognized herein generally follow the diagnosis of the chronospecies of $B$. minor recognized by Christensen (1995, 1999). According to the original diagnosis, differences between the two succeeding forms recognized in Norfolk are rather small. B. minor I is characterized by large guards with Birkelund Index about 4 (from 3.2 to 4.9 for individuals); mean value of Schatzky distance in samples range from 8 to $9.5 \mathrm{~mm}$; mean for $\mathrm{AA}$ and $\mathrm{FA}$ is $18.5-19^{\circ}$ and $28^{\circ}$, respectively. $B$. minor II is closely similar and is characterized by a stouter guard (Birkelund Index is about 3.5) and larger Schatzky distance ( 11.5-12 mm). In general, $B$. minor II differs form $B$. minor I by being a little bit stouter and having a larger Schatzky distance (cf. Christensen, 1995 and emended diagnosis of Christensen, 1999).

In the present study material from the Vistula section, the succeeding forms are characterized by the following mean values of selected characters (cf. also Fig. 13):

B. minor $\mathrm{I}: \mathrm{LAP}=53.8 \mathrm{~mm}$; LAEVF $=67.1 \mathrm{~mm} ; \mathrm{DVDP}=$ 13.64; $\mathrm{SD}=6.94 \mathrm{~mm}$ (from 4 to $9 \mathrm{~mm}$ ); $\mathrm{AA}=20^{\circ} ; \mathrm{FA}=29.1^{\circ}$; the Birkelund Index varies from 3.35 to 4.30 giving mean value c. 4.0 .

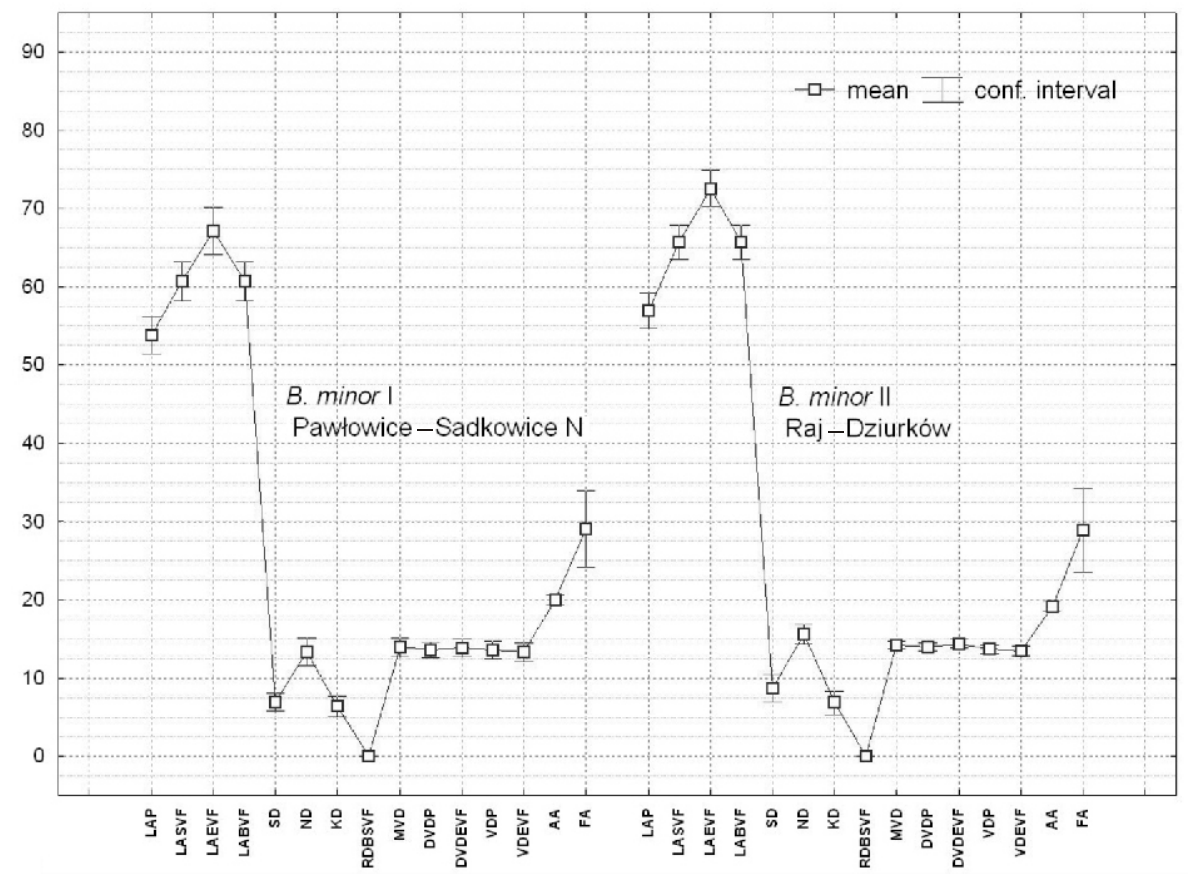

Fig. 13. Means and $95 \%$ confidence intervals of features in populations of B. minor from two succeeding intervals (Pawłowice-Sadkowice N and Raj-Dziurków) 
B. minor II: LAP $=57.0 \mathrm{~mm}$; LAEVF $=72.6 \mathrm{~mm}$; DVDP $=$ $14.00 ; \mathrm{SD}=8.74 \mathrm{~mm}$ (from 5.9 to $12.6 \mathrm{~mm}$ ); $\mathrm{AA}=19.1^{\circ} ; \mathrm{FA}=$ $28.9^{\circ}$; the Birkelund Index varies from 3.6 to 4.56 giving mean value c. 4.1 .

Keutgen et al. (2010) summarized that populations of B. minor I in Norfolk, Mons and the Maastricht area are characterized by a mean $\mathrm{BI}$ ranging from 3.7 to 4.2 and a mean SD ranging from 8.0 to $10.5 \mathrm{~mm}$, while the corresponding mean values of populations of $B$. minor II in these regions vary from 3.5 to 3.8 and 10.4 to $12.3 \mathrm{~mm}$, respectively. The corresponding values (BI and $\mathrm{SD}$ ) for the $B$. minor I from the Vistula valley are c. 4.0 and 6.9. In the case of $B$. minor $\mathrm{II}, \mathrm{BI}$ is 4.1 and $\mathrm{SD}$ is 8.74 .

Summarizing, the population of minor I and minor II from the Vistula valley is characterized by slightly smaller guards, with similar BI for the population of minor I and slightly larger BI for that of minor II. The SD of minor I from the Vistula section is generally similar to that of North European populations of minor I whereas minor II is characterized by a slightly smaller mean $\mathrm{SD}$ albeit reaching up to $12.6 \mathrm{~mm}$ in particular individuals. Whether these differences result from different development pattern of the populations or represent simple ecologic dependency is a question open to discussion. In my opinion such differences in the mean values are to be expected, reflecting regional particularities which I treat as taxonomical unimportant.

$B$. minor differs from $B$. posterior, in its significantly larger length-features, all diameters as well as ND, KD (Fig. 9). $B$. posterior is characterized by a markedly larger FA (mean $\left.=40^{\circ}\right)$ than $B$. minor $\left(\right.$ mean $\left.=27^{\circ}\right)$.

From Belemnitella sp. a, B. langei and B. najdini it differs in significantly larger length-features, all diameters as well as ND, KD (Fig. 9). Additionally $B$. najdini is characterized by a significantly larger $\mathrm{FA}\left(\right.$ mean $\left.=61^{\circ}\right)$ than $B$. minor $\left(\right.$ mean $\left.=27^{\circ}\right)$.

Occurrence. - In the Vistula section, B. minor is known from the Upper Campanian and Lower Maastrichtian (Tercis definition) and was recorded from: Pawłowice Posesja, Piotrawin, Sadkowice Szkoła, Sadkowice N, Raj, Raj N, Kłudzie $\mathrm{N}$ and Dziurków. Additionally, this taxon is known form broad areas of the North European Province: Belgium, the Netherlands and England.

\section{Belemnitella posterior Kongiel, 1962}

$$
\text { (Fig. 14A-N) }
$$

pars1962. Belemniella posterior Kongiel: 95, pl. 19, figs. 1-9. pars 1998b. Belemniella posterior Kongiel: 1-7 (Christensen, unpubl. report).

T y p e. - The holotype (Mcd 214), by original designation is the original of Kongiel (1962: 95, pl. 19, figs. 7-9), from Kołczyn in the Middle Vistula valley section; Upper Campanian, local level $r$ of Pożaryski (1938). It is refigured here (Fig. 14E1, E2) in addition to paratype (Fig. 14F1, F2) and are housed in the Mu-

\begin{tabular}{|c|c|c|c|c|c|c|c|}
\hline \multicolumn{8}{|c|}{ Belemnitella posterior - holotype (Mcd 214) and paratype (Mcd 212) } \\
\hline Specimen & LAP & LASVF & LAEVF & LABVF & SD & ND & KD \\
\hline Mcd 214 & 55.71 & 62.57 & 66.32 & 62.57 & 6.86 & 10.61 & 3.75 \\
\hline Mcd 212 & 63.62 & 69.98 & 72.07 & 69.98 & 6.36 & 8.45 & 2.09 \\
\hline \multicolumn{9}{|c|}{} \\
\hline RDBSVF & MVD & DVDP & DVDEVF & VDP & VDEVF & AA & FA \\
\hline 0.00 & 14.63 & 13.82 & 14.16 & 14.02 & 13.76 & 21.61 & 42.58 \\
\hline 0.00 & 15.05 & 14.76 & 15.03 & 14.76 & 14.57 & 21.39 & 60.28 \\
\hline
\end{tabular}

seum of the Earth in Warsaw of the Polish Academy of Sciences.

The specimens most similar to the means of population of B. posterior (cf. with descriptive statistics, Table. 4) are $\mathrm{Sad} / \mathrm{szk} / 029$ i Sad/szk/031, both from Sadkowice Szkoła.

$\mathrm{M}$ a t e r i a I. - 18 specimens from the Middle Vistula section: Pawl/pos/007, Sad/szk/012, Sad/szk/021, Sad/szk/031, Sad/szk/065, SadN/010, SadN/012, Raj/001, Raj/005, Raj/008, Raj/012, Raj/047, Raj/059, Pdole/022, Pdole/026, Dziu/005; Mcd 214 - holotype from the Kołczyn nad Wisłą and Mcd 212 paratype from the Solec nad Wisłą.

D e s c ri p t i o n. - Guard medium to large, sometimes very large, generally slender (mean LAEVF $=61.2 \mathrm{~mm}$; $\max$ LAEVF up to $74 \mathrm{~mm}$ ); LAP medium to large (mean LAP = $50.7 \mathrm{~mm}$; max LAP up to $62.4 \mathrm{~mm}$ ); the guard is subcylindrical to slightly lanceolate in ventral view and subconical to subcylindrical in lateral view and is markedly flattened ventrally; DVDP slightly larger than VDP. Mean value of Birkelund Index $\mathrm{BI}=4.2$ with an observed range 3.53-4.86. Apical end more or less acute, sometimes moderately obtuse, then with well-defined mucro.

$\mathrm{SD}$ small to medium (mean $=6.4 \mathrm{~mm}$ ); $\mathrm{ND}$ and $\mathrm{KD}$ medium with mean values $10.5 \mathrm{~mm}$ and $4.1 \mathrm{~mm}$ respectively. FA medium to large $\left(\right.$ mean $\left.=37.5^{\circ}\right)$; AA generally medium (mean = $\left.19.8^{\circ}\right)$. Shape of the bottom of the ventral fissure is usually straight, sometimes slightly curved.

Dorso-lateral longitudinal depressions and dorso-lateral double-furrows present, in some specimens relatively well-expressed. Vascular markings generally well-defined, mainly on ventral and lateral side. The complete biometry of Belemnitella posterior (morphogroup $b$ ) is summarized in Table 4 .

Discussion and remarks. - The specimens with complete biometry of morphogroup $b$ were compared with the small population from the Vistula section originally distinguished by Kongiel (1962) as Belemnitella posterior. Kongiel's species has been designated on the basis of 8 specimens from the uppermost Campanian and lowermost Maastrichtian (Boreal definition) of the Middle Vistula section, form the local levels $r, s, t$ and $u$ of Pożaryski (1938) and was included in the $B$. mucronata group (Kongiel, 1962). The mean values of particular features of this small topotype population of $B$. posterior analyzed by Kongiel are more or less equal to those of the present study's morphogroup $b$, which by the way, can also be treated as a topotype population for this species. Additionally, during Kohonen network simulations, the holotype and paratype of $B$. posterior (Fig. 14E, F) has been also included in morphogroup $b$ recognized herein

There is also a high similarity of morphogroup $b$ with what has been considered a population of $B$. posterior from the Piotrawin Quarry by Christensen (1998b). Christensen (1998b) in his unpublished report stated that $B$. posterior is a well defined albeit rare species. Within the study material from the Piotrawin pit in the Middle Vistula section, Christensen distinguished a population of $B$. posterior (26 specimens) with the following mean values of features: $\mathrm{LAP}=47.1 \mathrm{~mm} ; \mathrm{SD}=7.0 \mathrm{~mm}$; MVD = $12.0 \mathrm{~mm} ;$ DVDP $=12.0 \mathrm{~mm} ; \mathrm{VDP}=11.8 \mathrm{~mm}$; $\mathrm{AA}=19.8^{\circ} ; \mathrm{FA}=28.7^{\circ} ; \mathrm{BI}=3.9$. These values are only insignificantly different from the here presented population of morphogroup $b$ ( $=$ B. posterior). Consequently, I interpret morphogroup $b$ as representing $B$. posterior and the studied population may be regarded as statistically representative for this species.

$B$. posterior seems to be an East European species. Records in West European sections are either misinterpretations and have recently been referred to B. minor II (Robaszynski and Christensen, 1989; 


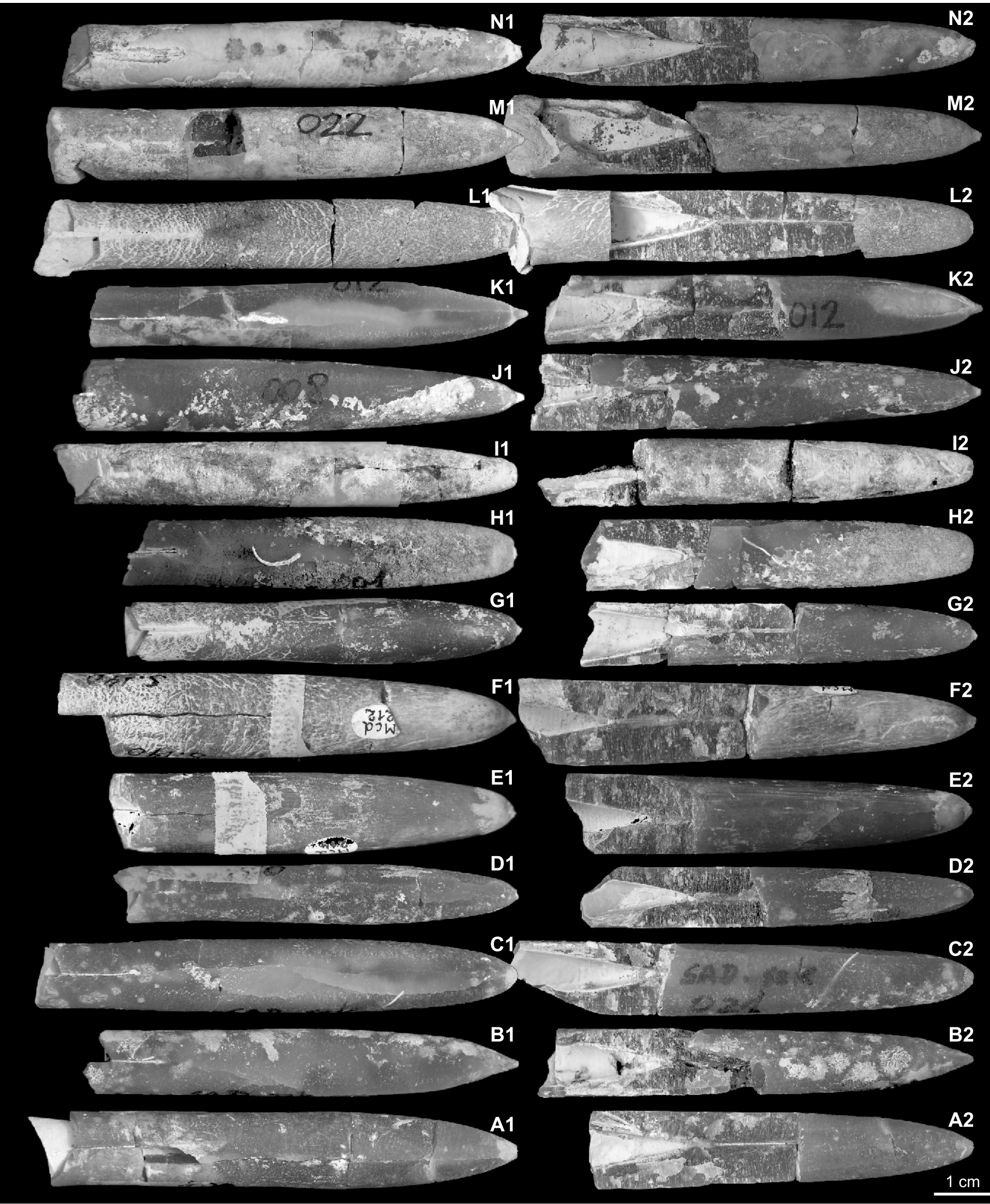

Fig. 14. Belemnitella posterior Kongiel, 1962

A - Pawł/pos/007, Pawłowice Posesja section; B-D - B - Sad/szk/012, C - Sad/szk/021, D - Sad/szk/031, Sadkowice Szkoła section; E Mcd 214, holotype, Kołczyn nad Wisłą (original of Kongiel, 1962); F - Mcd 212, paratype, Solec nad Wisłą (original of Kongiel, 1962); G SadN/012, Sadkowice N section; H-L - H - Raj/001, I - Raj/005, J - Raj/008, K - Raj/012, L - Raj/059, Raj section; M, N - M - Podole/022, N

- Podole/026, Podole section; other explanations as in Figure 11 
Biometry and descriptive statistics of the Belemnitella posterior (= morphogroup $b$ )

\begin{tabular}{|c|c|c|c|c|c|c|c|c|c|c|}
\hline $\begin{array}{c}\text { Variables } \\
{[\mathrm{mm}]} \\
{ }^{*} \text { in }\left[^{\circ}\right]\end{array}$ & $n$ & Mean & $\begin{array}{c}\text { Confidential } \\
\text { interval: } \\
-95 \%\end{array}$ & $\begin{array}{l}\text { Confidential } \\
\text { interval: } \\
+95 \%\end{array}$ & Median & Minimum & Maximum & Variance & $\begin{array}{l}\text { Standard } \\
\text { Deviation }\end{array}$ & $\begin{array}{c}\text { Standard } \\
\text { Error }\end{array}$ \\
\hline LAP & 16 & 50.68 & 48.00 & 53.37 & 50.20 & 43.31 & 62.40 & 25.47 & 5.047 & 1.262 \\
\hline LASVF & 16 & 57.04 & 54.20 & 59.87 & 56.09 & 49.32 & 68.23 & 28.33 & 5.323 & 1.331 \\
\hline LAEVF & 16 & 61.17 & 58.23 & 64.10 & 60.32 & 52.03 & 74.06 & 30.31 & 5.505 & 1.376 \\
\hline LABVF & 16 & 57.04 & 54.20 & 59.87 & 56.09 & 49.32 & 68.23 & 28.33 & 5.323 & 1.331 \\
\hline SD & 16 & 6.35 & 5.78 & 6.92 & 6.18 & 4.34 & 9.48 & 1.13 & 1.065 & 0.266 \\
\hline ND & 16 & 10.48 & 9.74 & 11.22 & 10.43 & 8.47 & 13.41 & 1.95 & 1.396 & 0.349 \\
\hline KD & 16 & 4.13 & 3.45 & 4.81 & 4.35 & 1.89 & 6.76 & 1.63 & 1.277 & 0.319 \\
\hline RDBSVF & 16 & 0.00 & - & - & 0.00 & 0.00 & 0.00 & 0.00 & 0.000 & 0.000 \\
\hline MVD & 16 & 12.06 & 11.40 & 12.73 & 11.95 & 9.71 & 14.49 & 1.56 & 1.249 & 0.312 \\
\hline DVDP & 16 & 11.95 & 11.31 & 12.59 & 11.91 & 9.79 & 14.19 & 1.45 & 1.203 & 0.301 \\
\hline DVDEVF & 16 & 12.06 & 11.40 & 12.72 & 11.99 & 9.93 & 14.25 & 1.55 & 1.243 & 0.311 \\
\hline VDP & 16 & 11.46 & 10.73 & 12.19 & 11.44 & 9.21 & 13.95 & 1.89 & 1.376 & 0.344 \\
\hline VDEVF & 16 & 11.20 & 10.52 & 11.89 & 11.23 & 9.08 & 13.31 & 1.64 & 1.280 & 0.320 \\
\hline$A A^{*}$ & 15 & 19.76 & 19.14 & 20.38 & 20.07 & 16.93 & 21.13 & 1.25 & 1.118 & 0.289 \\
\hline $\mathrm{FA}^{*}$ & 16 & 37.48 & 33.25 & 41.72 & 35.70 & 25.30 & 56.41 & 63.25 & 7.953 & 1.988 \\
\hline
\end{tabular}

Christensen, 1995) or are questionable at best (Schulz, 1978). Although $B$. posterior and $B$. minor II are relatively similar, the first is easily separated by its significantly larger fissure angle and smaller Schatzky distance.

B. posterior is slightly longer and has a slightly larger FA than Belemnitella sp. a (cf. Fig. 9). These differences are, however, small and it cannot be ruled out that these two forms represent in fact the same species. However, for the time being I treat these two forms separately.

$B$. posterior differs from $B$. langei by significantly larger length-features, slightly larger diameters and a markedly larger FA (Fig. 9). Additionally, B. langei possesses an acute apical end in contrast to the obtuse apical part in $B$. posterior.

From $B$. najdini the species $B$. posterior differs in significantly larger length-features, all diameters as well as ND and $\mathrm{KD}$ (Fig. 9). $B$. najdini is characterized by very large FA (mean = $62.2^{\circ}$ ) which is significantly larger than in $B$. posterior (mean $=$ $\left.37.5^{\circ}\right)$.

O c c u r r e n c e. - In the Vistula section, B. posterior is known form the Upper Campanian and Lower Maastrichtian (Tercis definition) and was recorded from: Pawłowice Posesja, Sadkowice Szkoła, Sadkowice N, Raj, Podole and Dziurków (single find).

\section{Belemnitella langei group}

R e m a r k s. - Kongiel (1962) included three species in the B. langei group: B. langei Jeletzky, 1948, B. minor Jeletzky, 1951 and $B$. najdini Kongiel, 1962. The conception of the $B$. langei group of Christensen differs from that of Kongiel (1962), because he placed $B$. minor into the $B$. mucronata group. Christensen also includedd B. pulchra Schulz, 1982, a latest Campanian to early Maastrichtian species (Tercis definition) in the $B$. langei group. All these forms are characterized by small guards, which are generally slender to very slender, with rather small Schatzky distances and large to very large fissure angles.
In the present study the conception of Christensen is generally adopted with the following species included unequivocally in the B. langei group: B. langei, and B. najdini; Belemnitella sp. $a$ is also included in this group, although with respect to its biometric characteristic it is transitional between $B$. langei and $B$. posterior (Fig. 9), thus between the mucronata and langei groups. For the time being, due to its uncertain taxonomic status, $B$. pulchra is also placed into this group. However, the latter species, with only minute differences from $B$. najdini, could be, in fact, its synonym.

Belemnitella langei Jeletzky, 1948 (Fig. 15A-P)

1948. Belemnitella langei Jeletzky: 599, text-figs. 3, 4.

1951b. Belemnitella langei Jeletzky; Jeletzky: 93, pl. 2, figs. 3, 5. pars 1962. Belemnitella langei Jeletzky; Kongiel: 78-79.

T y $\mathrm{p}$ e. - The holotype, by original designation, is the original of Jeletzky (1948: 599, text-figs. 3, 4) from the uppermost Campanian (Boreal definition) of the Sejm River area, a tributary of Desna River, Ukraine. It came from 1-2 m below the Campanian/Maastrichtian boundary (based on the FAD of Belemnella lanceolata) represented by a regional hiatus. It was refigured by Jeletzky (1951b: 93, pl. 2, figs. 3, 5) and Christensen (1986: pl. 7, fig. 5).

$\mathrm{M}$ a t e $\mathrm{r}$ i a I. -38 specimens from the Middle Vistula valley section: Pawl/pos/005, Pawl/pos/008, Sad/szk/004, Sad/szk/005, Sad/szk/009, Sad/szk/010, Sad/szk/011, Sad/szk/013, Sad/szk/014, Sad/szk/033, Sad/szk/034, Sad/szk/051, SadN/005, SadN/006, SadN/008, SadN/015, SadN/021, Piot/010, Piot/011, Piot/016, Piot/019, Raj/002, Raj/004, Raj/007, Raj/010, Raj/011, Raj/018, Raj/022, Raj/030, Raj/040, Raj/060, Raj/061, Raj/062, Raj/065, Raj/076, RajN/012, RajN/018, RajN/026.

D e s c ription. - Guard small, only sometimes medium-sized, generally slender to very slender (mean LAEVF = 

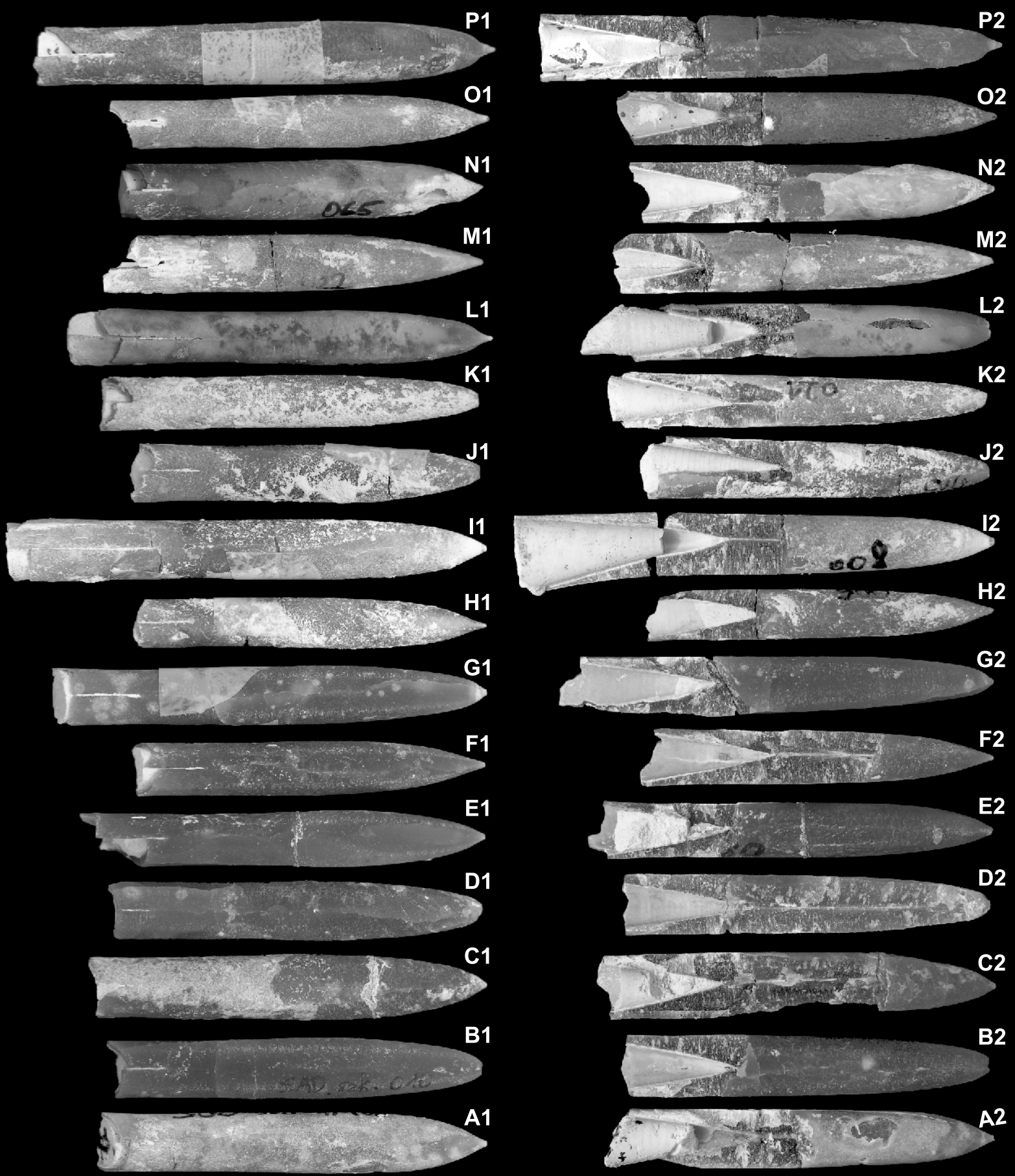

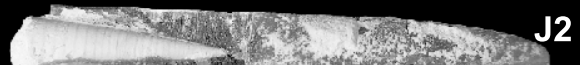
ares as a dis

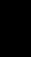
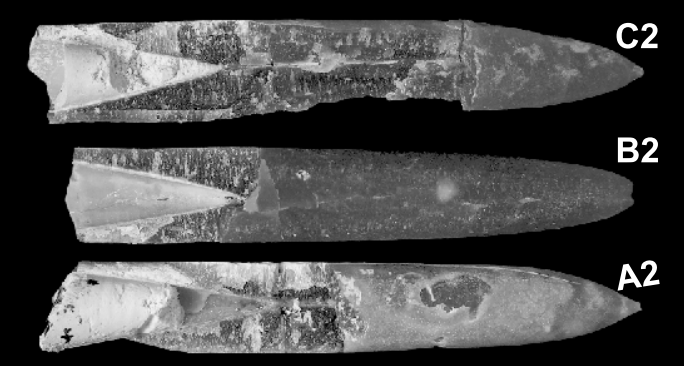

A - Pawł/pos/005, Pawłowice Posesja section; B-G - B - Sad/szk/010, C - Sad/szk/011, D - Sad/szk/014, E - Sad/szk/033, F Sad/szk/034, G - Sad/szk/051, Sadkowice Szkoła section; H-K - H - SadN/006, I - SadN/008, J - SadN/015, K - SadN/021, Sadkowice N section; L-N - L - Raj/010, M - Raj/022, N-Raj/065, Raj section; O, P - O - RajN/018, P - RajN/026, Raj N section; other explanations as in Figure 11 
$49.8 \mathrm{~mm}$; max LAEVF up to $58.7 \mathrm{~mm}$ ); LAP small (mean LAP = $39.2 \mathrm{~mm}$; max. LAP up to $46.7 \mathrm{~mm}$ ); the guard is generally subcylindrical, sometimes slightly lanceolate in ventral view and subcylindrical to conical in lateral view, tapering late. It is only slightly flattened ventrally; DVDP slightly larger than VDP. The mean value of Birkelund Index $\mathrm{BI}=4.3$ with an observed range of 3.66-5.22. Apical end acute to very acute, only rarely slightly obtuse with a rather poorly defined mucro.

$\mathrm{SD}$ small, sometimes medium-sized (mean $=7.0 \mathrm{~mm}$ ). ND medium to large (mean $=10.7 \mathrm{~mm}$ ); Kongiel distance generally small to medium (mean $=3.7 \mathrm{~mm}$ ). FA medium to large (mean $=31.0^{\circ}$ ); $\mathrm{AA}$ usually medium to very large (mean $=20.0^{\circ}$; max up to $23.8^{\circ}$ ). Shape of the bottom of the ventral fissure is usually straight, sometimes slightly curved posteriorly before reaching the outer surface of the guard.

Dorso-lateral longitudinal depressions and dorso-lateral double-furrows are present, but poorly developed. Vascular markings present only around the ventral fissure, in other cases weak; in some specimens longitudinal striae may be present. The complete biometry of Belemnitella langei (morphogroup c) is summarized in Table 5.

Discussion and remarks. - Belemnitella langei was designated by Jeletzky (1948), who subsequently (Jeletzky, 1951b) emended the diagnosis of his species. However, he did not study the internal characters of the holotype. The latter were finally reported by Christensen et al. (1975) and turned out to be in agreement with the emended diagnosis of Jeletzky (1951b). According to it, B. langei possessed a small and slender guard which is cylindrical or club-shaped in ventral view and conical or cylindrical in lateral view. The Schatzky distance varies from 5 to $7 \mathrm{~mm}$. FA usually oscillates in the range $40-50^{\circ}$, but may be $<40^{\circ}$ and up to $90^{\circ}$. AA is usually $23-25^{\circ}$ and the bottom of the ventral fissure is variable. It is worth mentioning, however, that accurate measurements of FA and AA could not be executed because of weathered alveolar part of the holotype and paratype.

Naidin (1952) understood this form more broadly and included in the $B$. langei group three forms: $B$. langei, B. minor (understood in the sense of its original diagnosis, not that of the holotype) and belemnites subsequently established by Kongiel (1962) as B. najdini.

$B$. langei distinguished by Birkelund (1957) was included by Christensen (1995) in the synonymy of $B$. minor III $(=B$. minor II) albeit with a query and subsequently was excluded from it (Christensen, 1999). B. langei sensu Birkelund was later given specific rank by Christensen (2000a) and referred to as $B$. schulzi.

Christensen (1986) distinguished B. aff. langei as an possible ancestor of $B$. langei, however, the stratigraphic control of his $B$. aff. langei is poor, and it differs markedly from the holotype and specimens of $B$. langei sensu Najdin from the Russian Platform. Moreover, in $B$. langei, the bottom of ventral fissure is usually complexly bent and the fissure angle is large, whereas in $B$. aff. langei the bottom is straight and the FA is very small (mean $=17^{\circ}$ ), which places this form rather closer to the $B$. mucronata group than to the $B$. langei group.

Schulz (1978) considered B. langei as a typical East European species and suggested that most of its records from Western Europe were misconceptions and should be assigned to $B$. cf. najdini. The conception of Christensen (1995) was different in that he included part of the specimens of $B$. cf. najdini recognized by Keutgen and Tuuk (1991) in the synonymy of $B$. najdini. However, the number of specimens analysed by these authors was small (a couple of specimens) and individual features varied markedly (Christensen, 1995). A larger sample from the same stratigraphic level was later studied by Keutgen and Jagt (1999), who showed the presence of two species, what they interpreted to be $B$. najdini and $B$. minor II.

The concept of $B$. langei, despite long-term studies, still remains uncertain and debatable because a topotype population has never been thoroughly described. The intraspecific variability is unknown due to the lack of statistically representative populations from the type locality. Thus, $B$. langei could be understood only in the sense of its holotype and paratype, which seem to fall to a large extent into the variability of what Christensen (1995) considered as B. langei from Norfolk, and at least in part fall into population of $B$. langei sensu Birkelund (= $B$. schulzi). Both those populations require further study to de-

Biometry and descriptive statistic of the Belemnitella langei (= morphogroup $c$ )

\begin{tabular}{|c|c|c|c|c|c|c|c|c|c|c|}
\hline $\begin{array}{c}\text { Variables } \\
{\left[\mathrm{mmm}^{\circ} \text { in }\left[^{\circ}\right]\right.}\end{array}$ & $n$ & Mean & $\begin{array}{c}\text { Confidential } \\
\text { interval: } \\
-95 \%\end{array}$ & $\begin{array}{l}\text { Confidential } \\
\text { interval: } \\
+95 \%\end{array}$ & Median & Minimum & Maximum & Variance & $\begin{array}{l}\text { Standard } \\
\text { Deviation }\end{array}$ & $\underset{\text { Error }}{\text { Standard }}$ \\
\hline LAP & 38 & 39.17 & 37.96 & 40.37 & 39.24 & 33.23 & 46.72 & 13.47 & 3.670 & 0.595 \\
\hline LASVF & 38 & 46.17 & 44.82 & 47.53 & 46.69 & 38.82 & 54.88 & 17.04 & 4.128 & 0.670 \\
\hline LAEVF & 38 & 49.82 & 48.35 & 51.30 & 49.90 & 41.70 & 58.74 & 20.24 & 4.499 & 0.730 \\
\hline LABVF & 38 & 46.17 & 44.82 & 47.53 & 46.69 & 38.82 & 54.88 & 17.04 & 4.128 & 0.670 \\
\hline SD & 38 & 7.01 & 6.66 & 7.35 & 7.04 & 4.45 & 8.41 & 1.10 & 1.049 & 0.170 \\
\hline ND & 38 & 10.66 & 10.14 & 11.17 & 10.54 & 7.95 & 14.06 & 2.45 & 1.565 & 0.254 \\
\hline KD & 38 & 3.65 & 3.27 & 4.03 & 3.85 & 0.96 & 5.90 & 1.33 & 1.154 & 0.187 \\
\hline RDBSVF & 38 & 0.00 & - & - & 0.00 & 0.00 & 0.00 & 0.00 & 0.000 & 0.000 \\
\hline MVD & 38 & 9.20 & 8.87 & 9.53 & 9.17 & 6.31 & 11.35 & 1.00 & 0.999 & 0.162 \\
\hline DVDP & 38 & 9.19 & 8.89 & 9.49 & 9.30 & 6.37 & 10.81 & 0.85 & 0.920 & 0.149 \\
\hline DVDEVF & 38 & 9.34 & 9.04 & 9.64 & 9.49 & 6.52 & 10.71 & 0.81 & 0.901 & 0.146 \\
\hline VDP & 38 & 8.78 & 8.47 & 9.08 & 8.86 & 5.81 & 10.68 & 0.88 & 0.939 & 0.152 \\
\hline VDEVF & 38 & 8.71 & 8.43 & 8.99 & 8.84 & 6.01 & 10.41 & 0.72 & 0.847 & 0.137 \\
\hline $\mathrm{AA}^{*}$ & 38 & 20.04 & 19.58 & 20.49 & 19.74 & 18.18 & 23.82 & 1.91 & 1.381 & 0.224 \\
\hline $\mathrm{FA}^{*}$ & 38 & 31.03 & 27.99 & 34.07 & 28.41 & 16.70 & 56.01 & 85.65 & 9.255 & 1.501 \\
\hline
\end{tabular}


cide whether or not they can be synonymized with the herein distinguished $B$. langei. Another complicating problem is the understanding of $B$. langei sensu Schulz from Kronsmoor.

The present study specimens with complete biometry of morphogroup $c$ resembles in most of its characters the original concept of $B$. langei Jeletzky, 1948, with reservation concerning especially the fissure angle, which is smaller in the Vistula population (mean $\mathrm{FA}=31^{\circ}$ ) than in the Norfolk populations where it oscillate between 50 and $60^{\circ}$.

In any case, I interpret morphogroup $c$ as representing $B$. langei since the differences in FA could be no more than palaeogeographical or palaeoecological variability. As mentioned above, a satisfying consensus concerning the taxonomic status of $B$. lange $i$ is very difficult to reach at the moment.

$B$. langei is relatively similar to $B$. najdini, from which it can be separated by its slightly smaller LAP and diameters and significantly larger ND and KD (Fig. 9). B. najdini is characterized by a significantly larger FA (mean $\left.=62.2^{\circ}\right)$ than that of $B$. langei $\left(\right.$ mean $\left.=31^{\circ}\right)$.

O c c u r r e n c e. - In the Middle Vistula section, B. langei is known form the Upper Campanian (Tercis definition) and was recorded from: Pawłowice Posesja, Sadkowice Szkoła, Sadkowice N, Piotrawin, Raj and Raj N and most probably from Podole.

Belemnitella najdini Kongiel, 1962

(Fig. 16A-R)

1962. Belemnitella najdini Kongiel: 79-80, pl. 17, figs. 7-9. 1974. Belemnitella langei najdini, Naidin: 223.

pars 1991. Belemnitella cf. najdini; Keutgen and Tuuk: 13. pars 1982. Belemnitella pulchra; Schulz: 284 pars1995. Belemnitella najdini; Christensen: 79-80.

?2006. Belemnitella langei najdini; Naidin and Beniamovski: 437 ?2012. Belemnitella langei najdini; Benyamovskiy et al: 353.

T y p e. - The holotype (Mcd 205), by original designation, is the original of Kongiel (1962: 79, pl. 17, figs. 7-9) from the Piotrawin Quarry, Upper Campanian (Tercis definition), local level $t$ of Pożaryski (1938). It is refigured here (Fig. 16P1, P2) in addition to paratype (Fig. 16R1, R2) and is housed in the Museum of the Earth in Warsaw of the Polish Academy of Sciences.

\begin{tabular}{|l|c|c|c|c|c|c|c|c|}
\hline \multicolumn{7}{|c|}{ Belemnitella najdini - holotype (Mcd 205) and paratype (Mcd 206) } \\
\hline Specimen & LAP & LASVF & LAEVF & LABVF & SD & ND & KD \\
\hline Mcd 205 & 43.66 & 50.49 & 50.04 & 49.77 & 6.83 & 6.38 & -0.45 \\
\hline Mcd 206 & 51.19 & 56.68 & 55.14 & 55.14 & 5.49 & 3.96 & -1.54 \\
\hline \multicolumn{8}{|c|}{} \\
\hline RDBSVF & MVD & DVDP & DVDEVF & VDP & VDEVF & AA & FA \\
\hline-0.72 & 10.29 & 9.94 & 10.26 & 10.15 & 10.04 & 20.36 & 88.56 \\
\hline-1.54 & 10.37 & 9.96 & 9.72 & 9.62 & 9.72 & 19.85 & 107.19 \\
\hline
\end{tabular}

M a t e r i a l. - 29 specimens from the Middle Vistula valley section: Pawl/pos/010, Sad/szk/008, Sad/szk/018, Sad/szk/041, Sad/szk/048, Sad/szk/069, SadN/018, Piot/002, Piot/004, Piot/005, Piot/008, Piot/009, Piot/013, Piot/014, Piot/015, Piot/020, Piot/022, Raj/003, Raj/019, Raj/021, Raj/026, Raj/037, Raj/039, Raj/054, Raj/073, RajN/024, Podole/017; Mcd 205 - holotype from the Piotrawin Quarry; Mcd 206 - paratype form the Solec nad Wisłą.
D e s c r i p t i o n. - Guard small, generally slender to very slender (mean LAEVF = $49.3 \mathrm{~mm}$; $\max$ LAEVF up to $56.5 \mathrm{~mm}$ ); LAP small (mean LAP $=41.8 \mathrm{~mm}$; max. LAP up to $48.8 \mathrm{~mm}$ ); the guard is subcylindrical or slightly lanceolate in ventral view and subcylindrical to subconical in lateral view and is only slightly flattened ventrally; DVDP slightly larger than VDP. Mean value of Birkelund Index $=4.4$ with an observed range of 4.01-5.48. Apical end acute or slightly obtuse with a variably defined mucro.

SD small, sometimes medium (mean $=6.2 \mathrm{~mm}$ ); $\mathrm{ND}$ and $\mathrm{KD}$ small or very small with mean values of $7.4 \mathrm{~mm}$ and $1.2 \mathrm{~mm}$, respectively, smallest values amongst all of the Belemnitella species studied herein (KD also with negative values, $\min \mathrm{KD}=$ $-1.4 \mathrm{~mm}$ ). FA very large (mean $=62.2^{\circ} ; \max$ up to $\left.100^{\circ}\right)$; $\mathrm{AA}$ usually medium to very large $\left(\right.$ mean $\left.=20.2^{\circ}\right)$; shape of the bottom of the ventral fissure commonly irregular, straight, curved or undulating, very often swept back posteriorly.

Dorso-lateral longitudinal depressions and dorso-lateral double-furrows present but weakly defined. Vascular markings present only around the ventral fissure, generally weakly developed or not present. The complete biometry of Belemnitella najdini (= morphogroup $d$ ) is summarized in Table 6.

Discussion and remarks. - Belemnitella najdini was designated by Kongiel (1962) and it seems to be closely allied to $B$. langei, being generally stratigraphically younger and it is typically included in the $B$. langei group. Due to the lack of statistically representative populations of $B$. najdini, this form has been understood so far only in the sense of its holotype and the relatively small topotype population studied by Kongiel (1962) and Christensen (1998b; unpubl. report) from the Middle Vistula section. Since the Vistula section is the type locality of $B$. najdini, the here established larger population (29 specimens) of $B$. najdini is treated as representative and topotypic for this species. Consequently, it is to this population that comparisons of other should be made.

$B$. najdini is generally considered a rare species and is known mainly on the basis of single specimens. This resulted in relatively wide ranges of variability of particular characters.

Naidin (1974) reported B. langei najdini from the uppermost Campanian [Boreal definition] of the Russian Platform.

Schulz (1982) designated a new species - B. pulchra of latest Campanian and Early Maastrichtian age (Tercis definition). Part of the Lower Maastrichtian specimens of $B$. najdini distinguished by Kongiel (1962) were assigned by Schulz (1982) to his new species $B$. pulchra, who stressed its distinctly lanceolate shape in ventral view. However, the differences between these two species are so minute that they could in fact represent a single Kongiel's species.

Christensen (1995) recognized a small population of $B$. najdini from the English Chalk (Norfolk) and included in its synonymy some of the specimens of $B$. cf. najdini recognized by Keutgen and Tuuk (1991). Although, the population analysed by Christensen is very small $(n=6)$ it shows high similarity to morphogroup $d(=B$. najdini) recognized herein, except for the larger FA in the Norfolk material (mean $\mathrm{FA}=98^{\circ}$ ).

Keutgen and Jagt (1999) recognized quite large population of $B$. najdini $(n=59)$ characterized by a markedly larger FA (mean $\mathrm{FA}=91^{\circ}$ with observed range $51-141^{\circ}$ ), than observed in the Vistula population of $B$. najdini.

Christensen (1998b) in an unpublished report concerning the belemnites from the Piotrawin pit of the Middle Vistula section recognized and analysed a small population of $B$. najdini ( 9 specimens). It differs in no significant respect from the popula- 


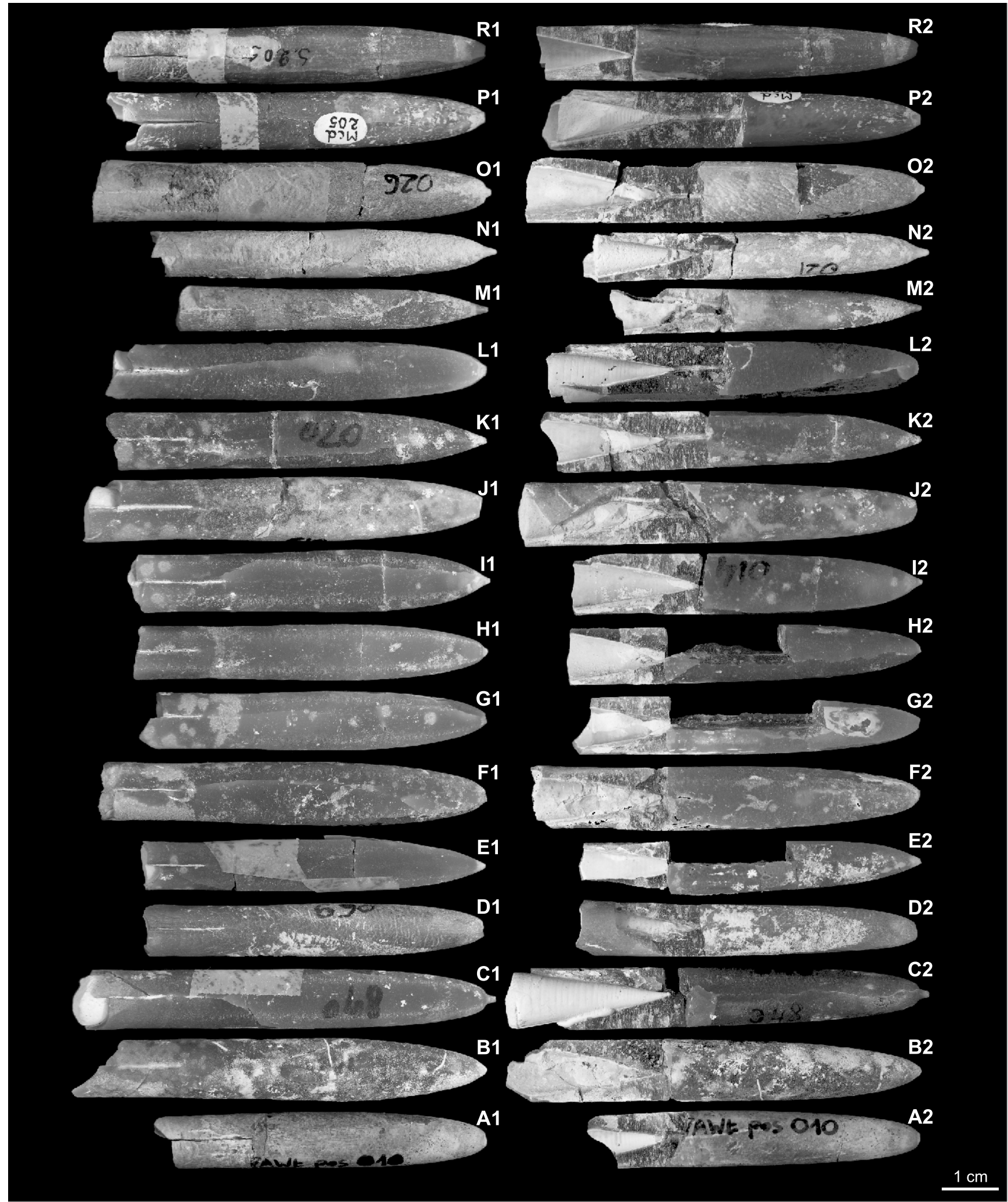

Fig. 16. Belemnitella najdini Kongiel, 1962

A - Pawł/pos/010, Pawłowice Posesja section; B-D - B - Sad/szk/041, C - Sad/szk/048, D - Sad/szk/069, Sadkowice Szkoła section; E SadN/018, Sadkowice N section; F-K - F - Piot/002, G - Piot/009, H - Piot/013, I - Piot/014, J - Piot/015, K - Piot/020, Piotrawin section; L-O - L - Raj/003, M - Raj/018, N - Raj/021, O - Raj/026, Raj section; P - Mcd 205, holotype, Piotrawin section (original of Kongiel, 1962); R - Mcd 206, paratype, Solec nad Wisłą (original of Kongiel, 1962); other explanations as in Figure 11 
Biometry and descriptive statistic of the Belemnitella najdini ( = morphogroup $d$ )

\begin{tabular}{|c|c|c|c|c|c|c|c|c|c|c|}
\hline $\begin{array}{c}\text { Variables } \\
{[\mathrm{mm}]} \\
*^{*} \text { in }\left[^{\circ}\right]\end{array}$ & $N$ & Mean & $\begin{array}{c}\text { Confidential } \\
\text { interval: } \\
-95 \%\end{array}$ & $\begin{array}{l}\text { Confidential } \\
\text { interval: } \\
+95 \%\end{array}$ & Median & Minimum & Maximum & Variance & $\begin{array}{l}\text { Standard } \\
\text { Deviation }\end{array}$ & $\begin{array}{c}\text { Standard } \\
\text { Error }\end{array}$ \\
\hline LAP & 27 & 41.84 & 39.89 & 43.80 & 42.04 & 30.93 & 48.79 & 24.5 & 4.95 & 0.952 \\
\hline LASVF & 27 & 48.07 & 46.09 & 50.04 & 49.27 & 36.06 & 55.26 & 24.9 & 4.99 & 0.960 \\
\hline LAEVF & 27 & 49.26 & 47.25 & 51.26 & 50.80 & 35.92 & 56.51 & 25.7 & 5.07 & 0.976 \\
\hline LABVF & 27 & 47.89 & 45.92 & 49.87 & 48.75 & 35.26 & 55.26 & 25.0 & 5.00 & 0.962 \\
\hline SD & 27 & 6.22 & 5.83 & 6.62 & 6.21 & 4.49 & 8.34 & 1.0 & 1.00 & 0.193 \\
\hline ND & 27 & 7.42 & 6.86 & 7.97 & 7.62 & 3.96 & 9.52 & 1.9 & 1.40 & 0.268 \\
\hline KD & 27 & 1.19 & 0.76 & 1.62 & 1.37 & -1.36 & 3.55 & 1.2 & 1.08 & 0.209 \\
\hline RDBSVF & 27 & -0.17 & -0.36 & 0.01 & 0.00 & -1.81 & 0.41 & 0.2 & 0.47 & 0.091 \\
\hline MVD & 27 & 9.98 & 9.39 & 10.58 & 10.23 & 6.90 & 13.59 & 2.3 & 1.50 & 0.289 \\
\hline DVDP & 27 & 9.93 & 9.38 & 10.48 & 10.26 & 7.33 & 12.88 & 1.9 & 1.39 & 0.268 \\
\hline DVDEVF & 27 & 9.97 & 9.42 & 10.51 & 10.30 & 7.53 & 12.95 & 1.9 & 1.38 & 0.265 \\
\hline VDP & 27 & 9.49 & 8.94 & 10.04 & 9.59 & 6.83 & 12.85 & 1.9 & 1.39 & 0.267 \\
\hline VDEVF & 27 & 9.37 & 8.84 & 9.90 & 9.56 & 6.78 & 12.60 & 1.8 & 1.34 & 0.258 \\
\hline $\mathrm{AA}^{*}$ & 27 & 20.16 & 19.84 & 20.48 & 20.10 & 18.60 & 22.22 & 0.7 & 0.81 & 0.156 \\
\hline $\mathrm{FA}^{*}$ & 27 & 62.22 & 55.85 & 68.58 & 60.32 & 36.97 & 99.79 & 258.7 & 16.09 & 3.096 \\
\hline
\end{tabular}

Explanations as in Table 2

tion of the group $d$ recognized herein, with the following means of selected features: $\mathrm{LAP}=44.5 \mathrm{~mm}$; $\mathrm{SD}=6.1 \mathrm{~mm} ; \mathrm{MVD}=$ $10.6 \mathrm{~mm}$; DVDP $=9.9 \mathrm{~mm} ; \mathrm{VDP}=9.9 \mathrm{~mm} ; \mathrm{AA}=19.8^{\circ} ; \mathrm{FA}=$ $62.1^{\circ} ; \mathrm{BI}=4.5$. All these values are statistically the same as the present study topotype population of $B$. najdini (= morphogroup $d$; cf. Fig. 9). For the above-mentioned reasons, I interpret specimens with the complete biometry of morphogroup $d$ as representing $B$. najdini.

O c c u r re n c e. - In the Vistula section, B. najdini is known form the Upper and uppermost Campanian (Tercis def.) and was recorded from: Pawłowice Posesja, Sadkowice Szkoła, Sadkowice N, Piotrawin, Raj, Raj N and Podole. It is also known from sparse locations in England, the Netherlands and from the Russian Platform.

\section{Belemnitella sp. a}

(Fig. 17A-K)

M a t e r i a I. - 20 specimens from Middle Vistula valley section: $\quad \mathrm{Pawl} / \mathrm{cm} / 001, \mathrm{Sad} / \mathrm{szk} / 002, \quad \mathrm{Sad} / \mathrm{szk} / 003$, Sad/szk/028, Sad/szk/029, Sad/szk/030, Sad/szk/032, Sad/szk/036, Sad/szk/038, Sad/szk/042, Sad/szk/050, Sad/szk/058, Sad/szk/060, Sad/szk/063, Piot/003, Piot/017, Raj/020, Raj/025, Raj/052, Raj/067.

Specimen Sad/szk/002 from the Sadkowice Szkoła section, south of the Solec nad Wisłą is the specimens most similar to the mean values of the population of morphogroup a (= Belemnitella sp. a); its biometric data are summarized below (cf. with descriptive statistics, Table 7).

\begin{tabular}{|c|c|c|c|c|c|c|c|}
\hline \multicolumn{7}{|c|}{ Biometric data of the Sad/szk/002 } \\
\hline Specimen & LAP & LASVF & LAEVF & LABVF & SD & ND & KD \\
\hline Sad/szk/002 & 45.32 & 51.00 & 55.04 & 51.00 & 5.68 & 9.72 & 4.05 \\
\hline \multicolumn{8}{|c|}{} \\
\hline RDBSVF & MVD & DVDP & DVDEVF & VDP & VDEVF & AA & FA \\
\hline 0.00 & 11.06 & 11.02 & 11.12 & 10.55 & 10.64 & 20.62 & 34.33 \\
\hline
\end{tabular}

D e s c r i p t i o n. - Guard medium-sized, generally slender (mean LAEVF = $57.3 \mathrm{~mm}$; max LAEVF up to $62.5 \mathrm{~mm}$ ); LAP medium (mean LAP $=46.4 \mathrm{~mm}$; max. LAP up to $50.7 \mathrm{~mm}$ ); the guard is usually subcylindrical (rarely slightly lanceolate) in ventral view and subconical to subcylindrical in lateral view and is flattened ventrally over its entire length; DVDP larger than VDP. Mean value of the Birkelund Index is 4.1 , with an observed range of 3.72-4.65. Apical end acute or obtuse; in the latter case with a rather well-defined mucro.

$\mathrm{SD}$ small to medium (mean $=6.6 \mathrm{~mm}$ ). ND and $\mathrm{KD}$ generally medium, sometimes large with mean values of $11.0 \mathrm{~mm}$ and $4.4 \mathrm{~mm}$, respectively. FA medium to large (mean $\left.=32.8^{\circ}\right)$. AA medium to large $\left(\right.$ mean $\left.=20.2^{\circ}\right)$. Shape of the bottom of the ventral fissure is commonly straight.

Dorso-lateral longitudinal depressions and dorso-lateral double-furrows rather poorly developed. Vascular markings generally variable, best expressed around the ventral fissure, they then weaken towards the ventral and lateral sides. The complete biometry of Belemnitella sp. $a$ is summarized in Table 7.

D is cus s i on and re marks. - Morphogroup a is the only morphogroup that cannot be assigned at a species-level to commonly recognized forms. The biometry of the population of Belemnitella sp. $a$ is very similar to the original diagnosis of $B$. minor Jeletzky, 1951, understood in the sense of its original diagnosis (but not with respect to the holotype). It is slightly smaller and thinner than B. mucronata and has larger alveolar and fissure angles. In addition, it is characterized by smaller values of SD, ND and KD, which also agrees with the original diagnosis (but not with the holotype).

The stratigraphic position of Belemnitella sp. $a$ is also compatible with the diagnosis of $B$. minor originally defined by Jeletzky (1951b), being younger than B. mucronata. It is possible that such species-populations commonly recognizable as $B$. langei minor, especially in Eastern Europe (Birkelund, 1957; Jeletzky, 1948, 1951b, 1958; Naidin, 1952) within the interval with "Pachydiscus wittekindi", "Bostrychoceras polyplocum" and "Belemnitella langei" was what Jeletzky had in mind when he 

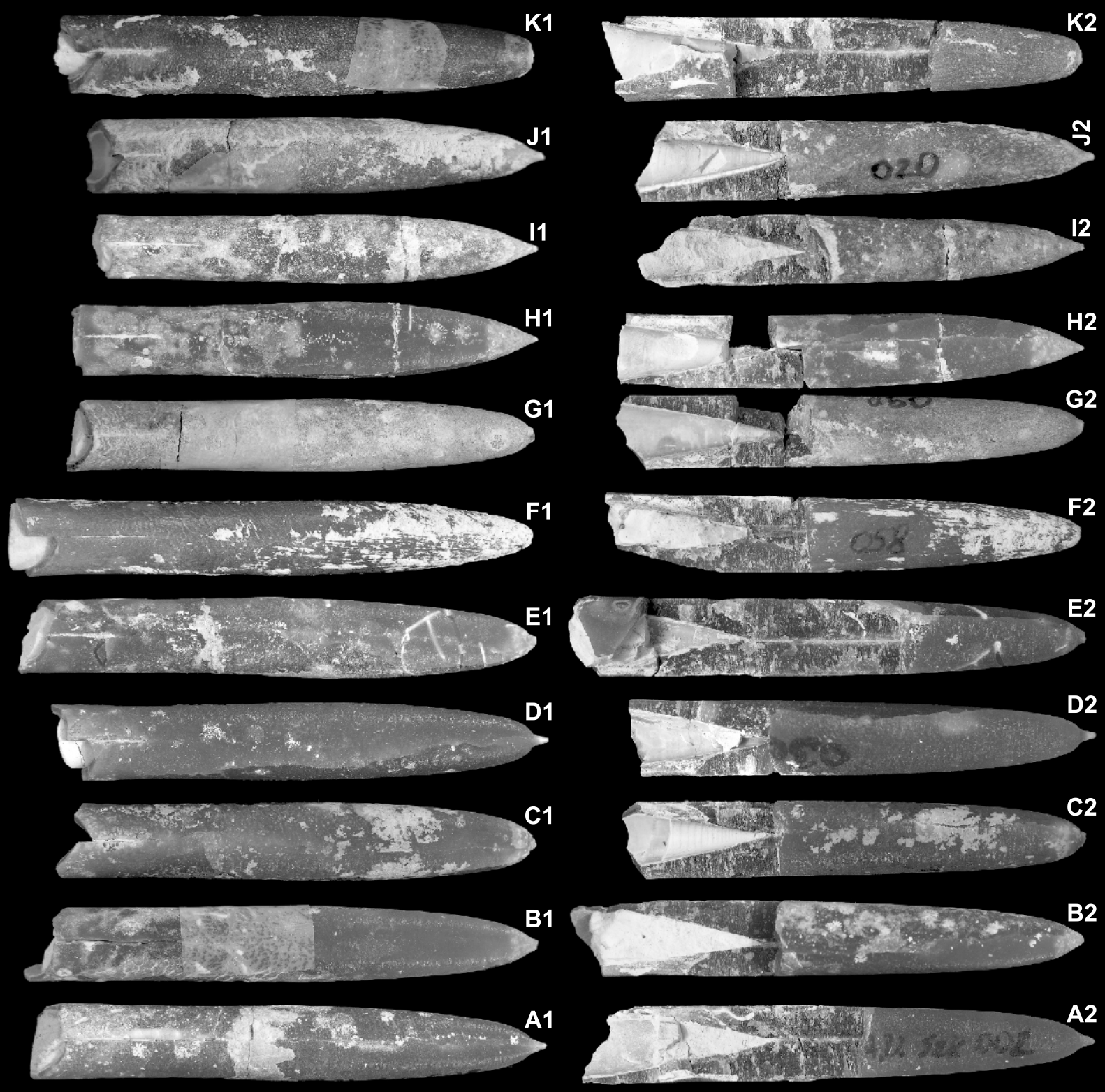

Fig. 17. Belemnitella sp. a

A-G - A- Sad/szk/002, B - Sad/szk/028, C - Sad/szk/030, D - Sad/szk/036, E - Sad/szk/042, F - Sad/szk/058, G - Sad/szk/060, Sadkowice Szkoła; H, I - H - Piot/003, I - Piot/017, Piotrawin; J, K - J - Raj/020, K - Raj/052, Raj; other explanations as in Figure 11 
Biometry and descriptive statistics of Belemnitella sp. a (= morphogroup a)

\begin{tabular}{|c|c|c|c|c|c|c|c|c|c|c|}
\hline $\begin{array}{c}\text { Variables } \\
\text { [mm] } \\
{ }^{\text {in }}\left[{ }^{\circ}\right]\end{array}$ & $n$ & Mean & $\begin{array}{c}\text { Confidential } \\
\text { interval: } \\
-95 \%\end{array}$ & $\begin{array}{l}\text { Confidential } \\
\text { interval: } \\
+95 \%\end{array}$ & Median & $\begin{array}{l}\text { Mini- } \\
\text { mum }\end{array}$ & $\begin{array}{l}\text { Maxi- } \\
\text { mum }\end{array}$ & Variance & $\begin{array}{l}\text { Standard } \\
\text { Deviation }\end{array}$ & $\underset{\text { Error }}{\text { Standard }}$ \\
\hline LAP & 20 & 46.36 & 45.11 & 47.60 & 46.24 & 39.65 & 50.69 & 7.08 & 2.662 & 0.595 \\
\hline LAEVF & 20 & 57.32 & 55.73 & 58.90 & 57.27 & 48.71 & 62.50 & 11.46 & 3.385 & 0.757 \\
\hline LABVF & 20 & 52.91 & 51.61 & 54.21 & 52.96 & 46.15 & 57.14 & 7.71 & 2.777 & 0.621 \\
\hline ND & 20 & 10.96 & 10.40 & 11.51 & 11.08 & 9.06 & 13.05 & 1.42 & 1.191 & 0.266 \\
\hline KD & 20 & 4.40 & 3.84 & 4.97 & 4.17 & 1.69 & 6.23 & 1.45 & 1.205 & 0.269 \\
\hline RDBSVF & 20 & 0.00 & - & & 0.00 & 0.00 & 0.00 & 0.00 & 0.000 & 0.000 \\
\hline MVD & 20 & 11.32 & 11.05 & 11.58 & 11.31 & 10.10 & 12.42 & 0.32 & 0.566 & 0.127 \\
\hline DVDP & 20 & 11.16 & 10.91 & 11.41 & 11.18 & 10.06 & 12.33 & 0.28 & 0.529 & 0.118 \\
\hline $\mathrm{AA}^{*}$ & 19 & 20.23 & 19.78 & 20.69 & 20.31 & 18.27 & 21.79 & 0.88 & 0.939 & 0.215 \\
\hline $\mathrm{FA}^{*}$ & 20 & 32.77 & 29.11 & 36.44 & 32.81 & 21.69 & 56.15 & 61.45 & 7.839 & 1.753 \\
\hline
\end{tabular}

Explanations as in Table 2

designated his $B$. minor. Although, the stratigraphic range of $B$. sp. $a$ is slightly higher than mentioned above.

Currently, B. minor is understood only in the sense of its holotype (not of the original diagnosis) and this definition is widely accepted, however, it is markedly different from the original diagnosis (i.e. Christensen, 1975, 1995; cf. also remarks to B. minor).
Belemnitella sp. 1

(Fig. 18A-B)

M a t e r i a I. - Two specimens from Vistula section form Raj $\mathrm{N}$ and Podole. Biometric data are summarized in the table below.

\begin{tabular}{|c|c|c|c|c|c|c|c|}
\hline \multicolumn{7}{|c|}{ Biometric data of the Podole/011 and Raj N/004, respectively } \\
\hline Specimen & LAP & LASVF & LAEVF & LABVF & SD & ND & KD \\
\hline Pdole/011 & 58.34 & 63.68 & 66.65 & 63.68 & 5.33 & 8.31 & 2.97 \\
\hline RajN/004 & 62.81 & 68.72 & 72.20 & 68.73 & 5.91 & 9.39 & 3.47 \\
\hline \multicolumn{7}{|l|}{} \\
\hline RDBSVF & MVD & DVDP & DVDEVF & VDP & VDEVF & AA & FA \\
\hline 0.00 & 15.78 & 15.22 & 15.10 & 14.98 & 14.52 & 19.10 & 54.13 \\
\hline 0.00 & 19.49 & 18.21 & 18.42 & 18.12 & 17.37 & 17.70 & 56.53 \\
\hline
\end{tabular}

On the one hand, Belemnitella sp. $a$ is similar to B. posterior, being slightly smaller and having a smaller FA (Fig. 9). On the other hand, Belemnitella sp. $a$ is also similar to B. langei, which is smaller and possesses a smaller FA than Belemnitella sp. a (Fig. 9). Thus, Belemnitella sp. a, in its biometric characteristic, is transitional between $B$. langei and B. posterior (cf. Fig. 9). Therefore, for the time being, Belemnitella sp. $a$ is left in open nomenclature.

From B. najdini, the recognized population of Belemnitella sp. a differs in markedly larger length-features, diameters as well as ND and KD which can reach in $B$. najdini even negative values (Fig. 9). B. najdini is characterized also by very large FA values (mean $=62.2^{\circ}$ ), which are significantly larger than in Belemnitella sp. a $\left(\right.$ mean $\left.=32.8^{\circ}\right)$.

O c c u r r e n c e. - In the Vistula section Belemnitella sp. $a$ is known form the Upper and uppermost Campanian (Tercis definition) and was recorded from: Pawłowice Cemetery, Sadkowice Szkoła, Sadkowice N, Piotrawin and Raj.
Description. - Both specimens Podole/011 and RajN/004 are large (LAEVF $=66.7 \mathrm{~mm}$ and $72.2 \mathrm{~mm}$; LAP $=$ $58.3 \mathrm{~mm}$ and $62.8 \mathrm{~mm}$ ), respectively, and are very thick and stout (MVD = $15.8 \mathrm{~mm}$ and $19.5 \mathrm{~mm}$ ). Both are cylindrical to slightly lanceolate in ventral view and cylindrical in lateral view and are markedly flattened ventrally over the entire length; DVDP only slightly larger than VDP. The Birkelund Index is 3.83 for Podole/011 and 3.45 for RajN/004. In both specimens the apical end is moderately obtuse with a well define mucro.

SD small (= $5.3 \mathrm{~mm}$ and $5.9 \mathrm{~mm})$; ND generally small $(=8.3$ and $9.4 \mathrm{~mm}$ ) and $\mathrm{KD}(=3.0$ and $3.5 \mathrm{~mm}$ ); fissure angle large, approximately $55^{\circ}$ and alveolar angle small $\left(=19.1\right.$ and $\left.17.7^{\circ}\right)$. Shape of the bottom of ventral fissure is straight, slightly swept back posteriorly, before reaching the outer surface of the guard.

Very well-developed dorso-lateral longitudinal depressions continue posteriorly into dorso-lateral double-furrows as far back as to the apical area. Vascular markings very well-defined especially on ventral and lateral side; longitudinal striae clearly visible on both dorsal and ventral side. 

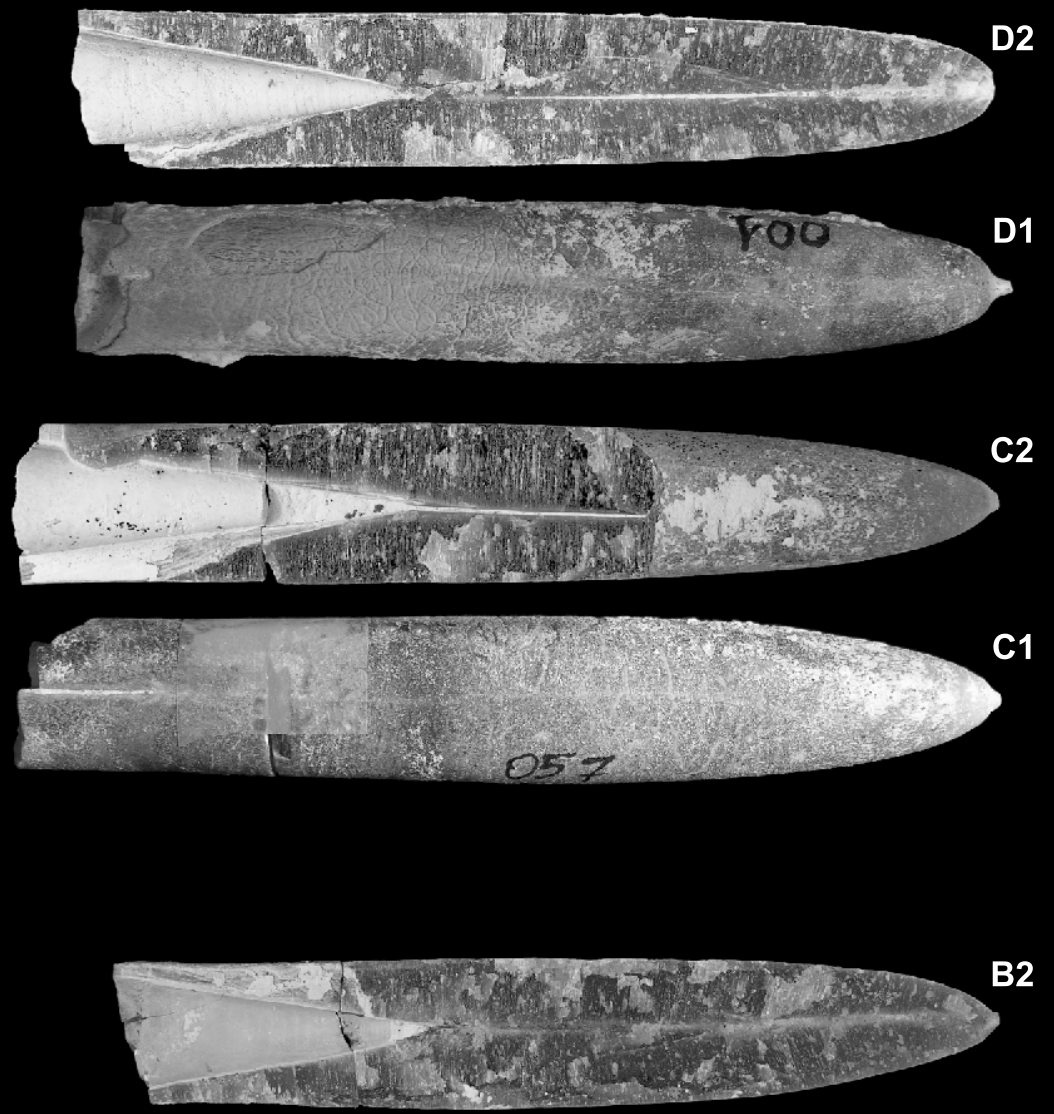

B2
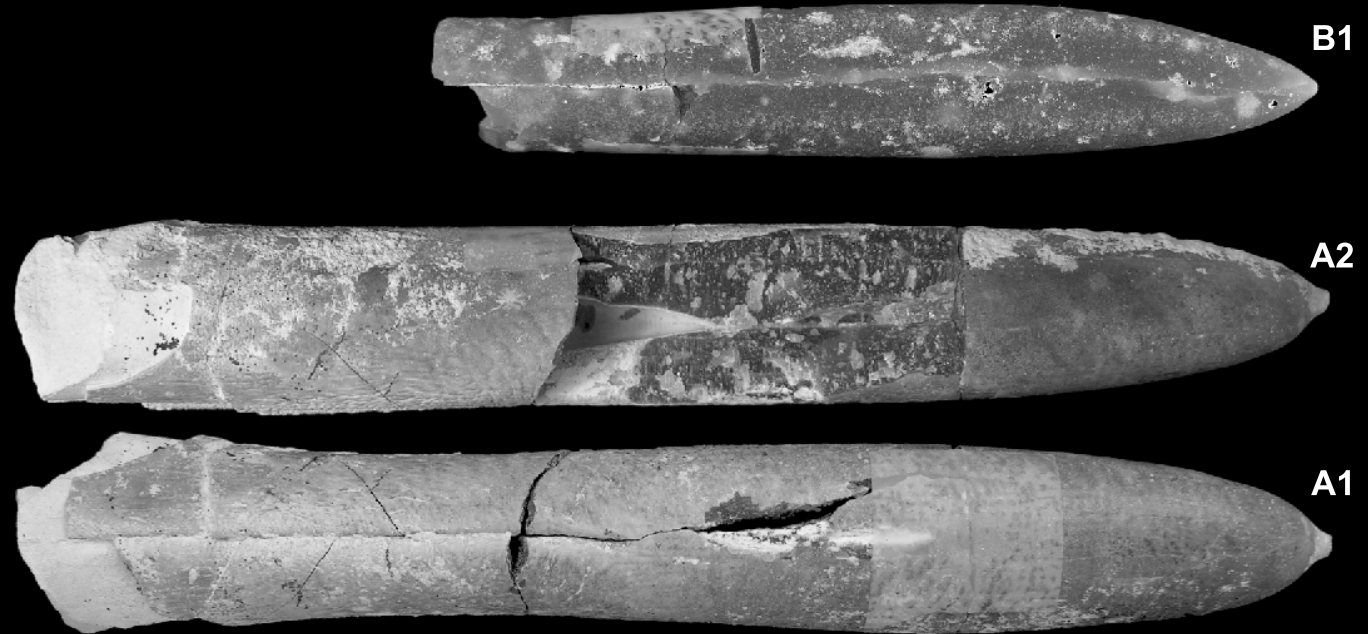

Fig. 18. Belemnitella sp. 1 (A, B) and Belemnitella sp. 2 (C, D)

A - RajN/004, RajN; B - Podole/011, Podole; C - RajN/057, RajN; D - SadN/001, Sadkowice N; other explanations as in Figure 11 
Discussion and remarks. - In several Kohonen-network simulations these two specimens always grouped together at the same winning neuron. Additionally, these two specimens were always classified on the SOM in the neighborhood of $B$. minor (= morphogroups $f$ ) and $B$. posterior $(=$ morphogroup $b)$. Such a classification on the SOM suggests its connection with the mucronata group.

The biometry of these specimens differs markedly in comparison from the rest of the morphogroups recognized herein and to other forms commonly recognizable elsewhere. Most probably, this form represents a new species, but for the time being it cannot completely be excluded that the specimens represent extreme variants of $B$. minor or $B$. posterior. Designation of a new species would thus be premature. Therefore, until statistically representative material becomes available, this form is left in open nomenclature.

O c c u r rence. - In the Vistula section Belemnitella sp. 1 is known form the Upper Campanian (Tercis definition) and was recorded from Raj $\mathrm{N}$ and Podole.

\section{Belemnitella sp. 2}

(Fig. 18C-D)

M a t e ri a l. - Two specimens from the Vistula section, from Sadkowice N and Raj N. Biometric data are summarized in the table below.

\begin{tabular}{|c|c|c|c|c|c|c|c|}
\hline \multicolumn{8}{|c|}{ Biometric data of the Sad N/001 and Raj N/057, respectively } \\
\hline Specimen & LAP & LASVF & LAEVF & LABVF & SD & ND & KD \\
\hline SadN/001 & 59.93 & 69.96 & 86.38 & 69.96 & 10.03 & 26.45 & 16.42 \\
\hline RajN/057 & 59.89 & 66.05 & 86.27 & 66.05 & 6.16 & 26.38 & 20.22 \\
\hline RDBSVF & MVD & DVDP & DVDEVF & VDP & VDEVF & AA & FA \\
\hline 0.00 & 16.54 & 15.65 & 16.21 & 16.17 & 15.34 & 19.23 & 9.40 \\
\hline 0.00 & 17.19 & 16.35 & 16.18 & 16.68 & 15.58 & 15.19 & 11.47 \\
\hline
\end{tabular}

Description. - Both specimens SadN/001 and RajN/057 are very large with LAEVF reaching values not recognized in other forms (LAEVF $=86.4 \mathrm{~mm}$ and $86.3 \mathrm{~mm}$, respectively); LAP large, being $59.9 \mathrm{~mm}$ in both specimens. All the diameters are very large, which makes the guard very stout. Both are cylindrical in ventral and lateral views and are markedly flattened ventrally over the entire length; DVDP only slightly smaller than VDP. The Birkelund Index is 3.83 for SadN/001 and 3.66 for RajN/057. In both specimens the apical end is moderately obtuse with a well-defined mucro.

SD medium to large $(=10.0 \mathrm{~mm}$ and $6.20 \mathrm{~mm})$. Other internal characters reach extreme values: ND $(=26.5 \mathrm{~mm}$ and $26.4 \mathrm{~mm}$ ) and $\mathrm{KD}(=16.4 \mathrm{~mm}$ and $20.2 \mathrm{~mm}$ ) are extremely large. FA extremely small $\left(=9.4\right.$ and $\left.11.5^{\circ}\right)$; AA small $(=19.2$ and $15.2^{\circ}$ ). Shape of the bottom of the ventral fissure is straight.

Dorso-lateral longitudinal depressions and dorso-lateral double-furrows well-developed. Vascular markings well-de- fined on the ventral and lateral side, especially around the ventral fissure

D i s c u s s i o n a n d re m a r k s. - The studied specimens are morphologically almost identical with respect to their external and internal characters. Extreme values of length from apex to the end of ventral fissure as well as Nowak distance, Kongiel distance and fissure angle, clearly separate these specimens from any other forms recognized herein and known from the available literature.

During the Kohonen-networks simulations, these two specimens always classified together with a high activation of the winning neuron. In addition, both specimens have activated neurons in the neighbourhood of $B$. minor (= morphogroups $f$ ) on the SOM (Fig. 5), suggesting their relationship with the mucronata group.

The biometry of these specimens does not allow assigning them to any of the morphogroups recognized herein, nor to forms known from literature. Most probably they represent a new species. Similarly, as in case of Belemnitella sp. 1, due to the small number of studied specimens (2), this form is left in open nomenclature, until a statistically representative collection becomes available.

O c c u r rence. - In the Vistula section Belemnitella sp. 2 is known form Sadkowice N and Raj N, from the Upper Campanian (Tercis definition).

Acknowledgements. This paper is partially based on a part of my Ph.D. thesis, devoted to the genus Belemnitella, but with several new additions, modifications and improvements, especially in the stratigraphic part. The thesis was undertaken at the Faculty of Geology of the University of Warsaw, under the supervision of Prof. I. Walaszczyk, to whom I would like to express my warmest thanks. Special thanks go to the Prof. A. Gasiński and late Prof. R. Marcinowski, the reviewers of my Ph.D. thesis, for their helpful remarks and continuous discussion. Ch. Wood, S. Long and J. Todd are thanked for help during my stay at the Natural History Museum, London, and in the British Geological Survey, Keyworth; W. Weitschat for help during my stay at the Museum of the Geological and Paleontological Institute of the University of Hamburg. Special thanks go to N. Keutgen who always served with help at different stages of my belemnite studies and his helpful remarks markedly improved the manuscript. Thanks go to my friends G. Niedźwiedzki and late A. Kin, who helped during my fieldwork. Warm thanks go to Dr. B. Studencka, a curator of Palaeozoology at the Museum of the Earth in Warsaw of the Polish Academy of Sciences, for help and for the loan of the Kongiel collection for comparison studies. The Ministry of Science and Higher Education is acknowledged for the financial support (grant nr 2 P04D 020 27).

\section{REFERENCES}

Arkhangelsky, A.D., 1912. Verkhnemelovyye otlozheniya vostoka evropeyskoy Rosii (in Russian). Materialy dla Geologii Rossii, 25: 1-631.
Benyamovskiy, V.N., Alekseev, A.S., Ovechkina, M.N., Vishnevskaya, V.S., Podgaetskiie, A.V., Pronin, V.G., 2012. Upper Campanian-lower Maastrichtian sections of the north- 
western Rostov region. Article 1. Description, paleontological assemblages, and lithobiostratigraphy. Stratigraphy and Geological Correlation, 20: 346-379.

Birkelund, T., 1957. Upper Cretaceous belemnites from Denmark. Biologiske Skrifter. Det Kongelige Danske Videnskabernes Selskab, 9: 1-69.

Błaszkiewicz, A., 1980. Campanian and Maastrichtian ammonites of the Middle Vistula River valley, Poland: a stratigraphic and paleontological study. Prace Instytutu Geologicznego, 92: 1-63.

Christensen, W.K., 1975. Upper Cretaceous belemnites from the Kristianstad area in Scania. Fossils and Strata, 7: 1-69.

Christensen, W.K., 1986. Upper Cretaceous belemnites from the Vomb Trough in Scania, Sweden. Sveriges Geologiska Undersökning, 57: 1-57.

Christensen, W.K., 1988. Upper Cretaceous belemnites of Europe state of the art. In: The Chalk District of the Euregio Meuse-Rhine (eds. M. Streel and M.J.M. Bless): 5-16.

Christensen, W.K., 1990. Upper Cretaceous belemnite stratigraphy of Europe. Cretaceous Research, 11: 371-386.

Christensen, W.K., 1993. Upper Cretaceous belemnitellids from the Båstad Basin, southern Sweden. Geologiska Föreningens i Stockholm Förhandlingar, 115: 39-57.

Christensen, W.K., 1995. Belemnitella from the Upper Campanian and Lower Maastrichtian Chalk of Norfolk, England. Special Papers in Palaeontology, 51: 1-84.

Christensen, W.K., 1996. A review of the Upper Campanian and Maastrichtian belemnite biostratigraphy of Europe. Cretaceous Research, 17: 751-766.

Christensen, W.K., 1997a. The Late Cretaceous belemnite family Belemnitellidae: taxonomy and evolutionary history. Bulletin of the Geological Society of Denmark, 44: 59-88.

Christensen, W.K., 1997b. Palaeobiogeography and migration in the Late Cretaceous belemnite family Belemnitellidae. Acta Palaeontologica Polonica, 42: 457-495.

Christensen, W.K., 1998a. Belemnitella from the lowermost Maastrichtian of Scania, southern Sweden. Bulletin of the Geological Society of Denmark, 45: 11-21.

Christensen, W.K., 1998b. Report on uppermost Uppe Campanian Belemnitella from the Piotrawin pit, central Poland (unpublished report), May 1998, Copenhagen (housed at the Faculty of Geology of the University of Warsaw together with currently studied belemnite collection).

Christensen, W.K., 1999. Upper Campanian and Lowe Maastrichtian belemnites from the Mons Basin, Belgium. Bulletin de l'Institut Royal des Sciences Naturelles de Belgique, Sciences de la Terre, 69: 97-137.

Christensen, W.K., 2000a. Belemnitella schulzi sp. nov. from the uppermost Campanian and lowest Maastrichtian chalks of northwest Germany and Denmark. Acta Geologica Polonica, 50: 55-66.

Christensen, W.K., 2000b. Gradualistic evolution in Belemnitella from the middle Campanian of Lower Saxony, NW Germany. Bulletin of the Geological Society of Denmark, 47: 135-163.

Christensen, W.K., Ernst, G., Schmid, F., Schulz, M.-G., Wood, C.J., 1973. Comment on proposal for designation of a neotype for the Upper Cretaceous Belemnites mucronatus Link, 1807. Z. N. (S.) 1160. Geologisches Jahrbuch, A9: 41-45.

Christensen, W.K., Ernst, G., Schmid, F., Schulz, M.-G., Wood, C.J., 1975. Belemnitella mucronata mucronata (Schlotheim, 1813) from the Upper Campanian: neotype, biometry, comparisons and biostratigraphy. Geologisches Jahrbuch, A28: 27-57.

Christensen, W.K., Ernst, G., Schmid, F., Schulz, M.-G., Wood, C.J., 1982. Belemnites mucronatus (Coleoidea): proposed use of the plenary powers to attribute this name to Schlotheim, 1813 and to designate a neotype in conformity with current usage. $Z$. N. (S.) 1160. Bulletin of the Zoological Nomenclature, 39: 141-145.

D'Orbigny, A., 1840-1842. Paléontologie francaise: Terrains crétacés, 1, Céphalopodes. Masson, Paris: 1-120 (1840); 121-430 (1841); 431-662 (1842)
Fausett, L., 1994. Fundamentals of Neural Networks. Prentice Hall, New York.

Hancock, J.M., Gale, A.S. (with contributions from Gardin, S., Kennedy, W.J., Lamolda, M.A., Matsumoto, T. and Najdin, D.P.), 1996. The Campanian Stage. Bulletin de l'Institut Royal des Sciences Naturelles de Belgique (Supplement), 66: 103-109.

Haykin, S., 1994. Neural Networks: A Comprehensive Foundation. Macmillan Publishing, New York.

Herrmannsen A.N., 1846. Indices generum malacozoorum. Primordia, 1: 1-636. Kassel.

Jagt, J.W.M., 2012. Belemnitellid coleoids (Mollusca Cephalopoda) from the type Maastrichtian, the Netherlands and Belgium. Scripta Geologica Special Issue, 8: 93-111.

Jeletzky, J.A., 1941. Über die Sistematik und die Phylogenie der Belemniten der Oberen Kreide (in Ukrainian with German summary). Doklady Akademii Nauk SSSR, 2: 23-30. Kiev.

Jeletzky, J.A., 1948. Zur Kenntnis der Oberkreide der Dnjepr-Donez-Senke und zum Vergleich der russischen borealen Oberkreide mit derjenigen Polens und Nordwesteuropas. Geologiska Föreningens i Stockholm Förhandlingar, 70: 583-602.

Jeletzky, J.A., 1950. Some nomenclatorial and taxonomic problems in paleozoology. Journal of Paleontology, 24: 19-38.

Jeletzky, J.A., 1951a. The Place of the Trimingham and Norwich Chalk in the Campanian-Maastrichtian Succession. Geological Magazine, 88: 197-208.

Jeletzky, J.A., 1951b. Die Stratigraphie und Belemnitenfauna des Obercampan und Maastricht Westfalens, Nordwestdeutschlands und Dänemarks, sowie einige allgemeine GliederungsProbleme der jüngeren borealen Oberkreide Eurasiens. Beihefte Geologisches Jahrbuch, 1: 1-142.

Jeletzky, J.A., 1958. Die jüngere Oberkreide (Oberconiac bis Maastricht) Südwestrusslands und ihr Vergleich mit der Nordwest- und Westeuropas. Beihefte Geologisches Jahrbuch, 33: 1-157

Jeletzky, J.A., 1964. Belemnites mucronatus Link, 1807 (Cephalopoda, Belemnitida): proposed designation of a neotype under the Plenary Powers Z.N.(S.) 1160. Bulletin of Zoological Nomenclature, 21: 268-296.

Keutgen, N., 2011. The belemnite zonation of the uppermost Cretaceous in the Maastricht-Aachen-Liege, Brabant-Mehaigne and Mons areas (Belgium, southeast Netherlands). Netherlands Journal of Geosciences, 90: 165-17.

Keutgen, N., Jagt, J.W.M., 1999. Late Campanian belemnite faunas from Liège-Limburg (NE Belgium, SE Netherlands). Geological Survey of Belgium, Professional Paper, 1998/2, 287: $1-34$.

Keutgen, N., Tuuk, L.A., van der, 1991. Belemnites from the Lower Maastrichtian of Limburg, Aachen and Liege. Mededelingen Rijks Geologische Dienst, 44 (for 1990): 1-39.

Keutgen, N., Jagt, J.W.M., Felder, P.J., Jagt-Yazykova, E.A., 2010. Stratigraphy of the upper Vijlen Member (Gulpen Formation; Maastrichtian) in northeast Belgium, the southeast Netherlands and the Aachen area (Germany), with special reference to belemnitellid cephalopods. Netherlands Journal of Geosciences, 89: 109-136.

Kohonen, T., 1982. Self-organized formation of topologically correct feature maps. Biological Cybernetics, 43: 59-69.

Kongiel, R., 1962. On belemnites from the Maastrichtian, Campanian and Santonian sediments in the Middle Vistula Valley (Central Poland). Prace Muzeum Ziemi, 5: 1-148.

Naidin, D.P., 1952. Verkhnemelovyye belemnity Zapadnoy Ukrainy (in Russian). Trudy Moskovskogo Geologicheskogo Razvedochnogo Instituta imieni S. Ordzhonikidze, 27: 1-170.

Naidin, D.P., 1964a. Verkhnemelovyye belemnity Russkoy Platformy i sopredelnykh oblastey (in Russian). Izdatelstvo Moskovskogo Universiteta.

Naidin, D.P., 1964b. Verkhnemelovye belemnitelly i belemnelly Russkoy Platformy i nekotorykh sopredelnykh oblastey (in Rus- 
sian). Byulleten Moskovskogo Obshchestva Ispytateley Prirody, Otdel Geologicheskiy, 39: 85-97.

Naidin, D.P., 1974. Subclass Endocochlia - Order Belemnitidae. In: Atlas of the Upper Cretaceous fauna of Donbass (ed. G.Ya Krumgol'ts ): 197-240. Nedra, Moscov.

Naidin, D.P., 1975. Verkhnemelovye belemnity Yevrazii (in Russian). In: Evolution and Change of Organic Kingdom at the Mesozoic-Caenozoic Boundary (eds. V.V. Menner, M.M. Moskvin D.P. Najdin, A.N. Solovev and V.N. Shimanskiy): 91-108. Palaeontological Institute, Academy of Sciences, USSR, Nauka, Moscow.

Naidin, D.P., 1979. Vergleichende Stratigraphie der Oberen Kreide der Russischen Tafel und West-Europas. In: Aspekte der Kreide Europas (ed. J. Wiedmann). International Union of Geological Sciences, A6: 497-510.

Naidin, D.P., Beniamovski, V.N., 2006. The Campanian-Maastrichtian Stage Boundary in the Aktulagai Section (North Caspian Depression). Stratigraphy and Geological Correlation, 4: 433-443.

Niebuhr, B., Hampton, M.J., Gallagher, L.T., Remin, Z., 2011. Integrated stratigraphy of Kronsmoor (northern Germany), an international reference section for the base of the Maastrichtian in the Boreal Realm. Acta Geologica Polonica, 61: 193-214.

Nikitin, I.I., 1958. Upper Cretaceous belemnites from the Northeastern flank of the Dniepr-Donetsk Depression. Akademia Nauk Ukrainskoi RSR, Trudy Instituta Geologichnykh Nauk, Seria Stratygrafii i Paleontologii, 20: 1-92.

Nowak, J., 1913. Untersuchungen über die Cephalopoden der oberen Kreide in Polen. III Teil. Bulletin International de l'Académie des Sciences de Cracovie, Classe des Sciences Mathématiques et naturelles, Série B, Sciences Naturelles, 1913: 335-415.

Odin, G.S. (compiler), 1996. Definition of a Global Boundary Stratotype Section and Point for the Campanian and Maastrichtian boundary. Bulletin de I'Institut Royal des Sciences Naturelles de Belgique, Sciences de la Terre, 66: $111-117$

Odin, G.S., ed., 2001. The Campanian-Maastrichtian boundary: characterisation at Tercis les Bains (France): correlation with Europe and other continents. Developments in Palaeontology and Stratigraphy Series, 19.

Odin, G.S., Lamaurelle, M.A., 2001. The global Campanian-Maastrichtian stage boundary. Episodes, 24: 229-238.

Olferev, A.G., Beniamovski, V.N., Vishnevskaya, V.S., Ivanov, A.V., Kopaevich, L.F., Pervushov, E.M., Seltser, V.B., Tesakova, E.M., Kharitonov, V.M., Shcherbinina, E.A., 2007. Upper Cretaceous deposits in the northwest of Saratov oblast, Part 1: litho-and biostratigraphic analysis of the Vishnevoe section. Stratigraphy and Geological Correlation, 15: 610-655.

Patterson, D., 1996. Artificial Neural Networks. Prentice Hall, Singapore.

Pavlow, A.P., 1914. Yurskiye i nizhnemelovye Cephalopoda Severnoi Sibirii (in Russian). Zapisky Imperatorskoy Akademii Nauk 8, Po Fiziko-Matematicheskomu Otdeleniu, 21: 1-68.

Peake, N.B., Hancoock, J.M., 1961. The Upper Cretaceous of Norfolk. Transactions of the Norfolk and Norwich Naturalists Society, 19: 293-339.

Peake, N.B., Hancoock, J.M., 1970. The Upper Cretaceous of Norfolk. In: The Geology of Norfolk (eds. G.P. Larwood and B.M. Funnell): 296-376. Norfolk Geological Society.

Peryt, D., Dubicka, Z., 2015. Foraminiferal bioevents in the Upper Campanian to lowest Maastrichtian of the Middle Vistula River section, Poland. Geological Quarterly, 59 (4): 814-830.
Plasota, T., Nawrocki, J., Walaszczyk, I. 2015. Magnetostratigraphy of the Campanian/Maastrichtian boundary succession from the Middle Vistula River section, central Poland. Geological Quarterly, 59 (4): 831-842.

Pożaryski, W., 1938. Senonstratigraphie im Durchbruch der Weichsel zwischen Rachów und Puławy in Mittelpolen (in Polish with German summary). Biuletyn Państwowego Instytutu Geologicznego, 6: 3-94.

Pożaryski, W., 1974. Tektonika, cz. 1. Niż Polski (in Polish). In: Budowa geologiczna Polski (ed. W. Pożaryski): 2-34. Wyd. Geol., Warszawa.

Remin, Z., 2007. Analiza paleontologiczna i znaczenie stratygraficzne belemnitów górnego kampanu i dolnego mastrychtu profilu doliny środkowej Wisły (in Polish). Ph.D. thesis, University of Warsaw, Warszawa.

Remin, Z., 2008. Artificial Kohonen neural networks as a tool in paleontological taxonomy - an introduction and application to Late Cretaceous belemnites (in Polish with English summary). Przegląd Geologiczny, 56: 58-66.

Remin, Z., 2012. The Belemnella stratigraphy of the Campanian-Maastrichtian boundary: a new methodological and taxonomic approach. Acta Geologica Polonica, 62: 495-533.

Remin, Z., Machalski, M., Jagt, J.W.M., 2015. The stratigraphically earliest record of Diplomoceras cylindraceum (heteromorph ammonite) - implications for Campanian/Maastrichtian boundary definition. Geological Quarterly, 59 (4): 843-848.

Robaszynski, F., Christensen, W.K., 1989. The Upper Campanian-Lower Maastrichtian chalks of the Mons basin, Belgium: a preliminary study of belemnites and foraminifera in the Harmignies and Ciply areas. Geologie en Mijnbouw, 68: 391-408.

Schlotheim, E.F., von, 1813. Beiträge zur Naturgeschichte der Versteinerungen in geognostischer Hinsicht. Leonhard's Taschenbuch für die gesammte Mineralogie, 7: 3-134.

Schulz, M.-G., 1978. Zur Litho- und Biostratigraphie des Obercampan-Untermaastricht von Lägerdorf und Kronsmoor (SW-Holstein). Newsletters on Stratigraphy, 7: 73-89.

Schulz, M.-G. 1979. Morphometrisch-variationsstatistische Untersuchungen zur Phylogenie der Belemniten-Gattung Belemnella im Untermaastricht NW-Europas. Geologisches Jahrbuch, A47: 3-157.

Schulz, M.-G., 1982. Erste Nachweis der Belemnitengattung Belemnitella (B. pulchra n. sp.) im mittleren Untermaastricht NW-Deutschlands. Geologisches Jahrbuch, A61: 279-293.

Sharpe, D., 1853. Description of the fossil remains of Mollusca found in the Chale of England. Part I. Cephalopoda. Palaeontographical Society Monographs: 1-26.

Vassilenko, V.K., Rassmyslowa, S.S., 1950. Sistematika belemnitell (in Russian). Doklady Akademii Nauk SSSR, 74: 603-606.

Walaszczyk, I., 2004. Inoceramids and inoceramid biostratigraphy of the Upper Campanian to basal Maastrichtian of the Middle Vistula River section, central Poland. Acta Geologica Polonica, 54: 95-168.

Walaszczyk, I., 2012. Integrated stratigraphy of the Campanian-Maastrichtian boundary succession of the Middle Vistula River (central Poland) section; introduction. Acta Geologica Polonica, 62: 485-493.

Wood, C.J., 1988. The stratigraphy of the chalk of Norwich. Bulletin of the Geological Society of Norfolk, 38: 3-120.

Wrzołek, T., Remin, Z., 2008. Palaeontological modeling - classical recognition of genera and species in rugose corals vs. self-organizing Kohonen networks classification. 9th Paleontological Conference, Warszawa, Polska: 103-105. 